\title{
Current Research of the Leiden-Turin Archaeological Mission in Saqqara. A Preliminary Report on the 2018 Season
}

\author{
Paolo Del Vesco, Christian Greco, Miriam Müller, Nico Staring and Lara Weiss \\ With contributions by Valentina Gasperini, Corinna Rossi, Alice Salvador, Ali Jelene Scheers, Sarah Schrader \\ and Nicholas Warner
}

In 2015, the Museo Egizio in Turin joined the Leiden expedition to Saqqara, in the area south of the Unas causeway. This report presents the expedition's new approach as well as some first results of this new cooperation. In the 2018 season, the Leiden-Turin expedition worked in the northern sector of its concession, covering an area of ca. $250 \mathrm{sqm}$ just north of the tomb of Maya. Here Late Antique layers overlie a windblown deposit containing some simple burials and numerous "embalmers' caches", some of which yielded marl clay cups with hieratic labels. An overview of both the pottery and the human remains found during this season is provided in the present report. Below the wind-blown deposit is a level with Ramesside funerary chapels and shafts. One of them has a remarkable decoration including six small-format figures carved in high relief in the middle of its back wall. The shaft of another chapel was also excavated, revealing several plundered chambers which yielded only scanty finds. A large mud-brick wall exposed during the previous season turned out to belong to the outer wall and pylon entrance of a monumental tomb, whose owner's name has not been found yet.

A photogrammetric survey by a team of the Politecnico di Milano yielded a 3D model of the dig (included in the web version of this report), as well as several 3D models of the monumental tombs (completed or in the making). During the season, conservation work was carried out on several tombs and on the newly discovered Ramesside chapel.

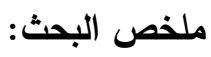

شارك المتحف المصري بتورينو في عام 2015 بالعمل مع بعثة لايدن فى سقارة، في المنطقة الواقعة جنوب طريق أوناس

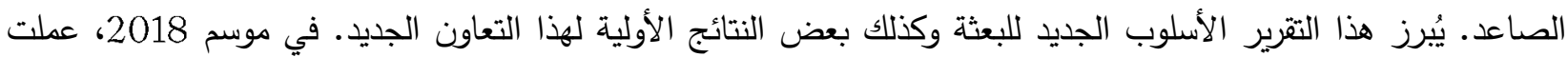
بعثة "لايدن - تورينو" في القطاع الثمالي الممنوح لهم، وهو ما يغطي مساحة حوالى 250 متر مربع شمالي مقبرة مايا. تكسو طبقات العصور القديمة المتأخرة في هذه المنطقة رواسب تجمعت بعوامل الرياح، وتحتوي على بعض المدافن البسيطة والعديد من "مقتتيات التحنيط"، بعضها إشتمل على أكواب طينية من الطين الكلسي بعلامات مكتوبة بالخط الهيراطيقي. يوفر هذا التقرير لمحة عامة عن كل من الفخار والبقايا البشرية التي عُثر عليها خلال هذا العام. أسفل الرواسب المحمولة بالرياح يوجد مستوى مكون من الأماكن المخصصة للصلاة وتقديم القرابين وأكثر من بئر كلها تعود إلى حقبة الرعامسة. أحدها يحتوي على لهى

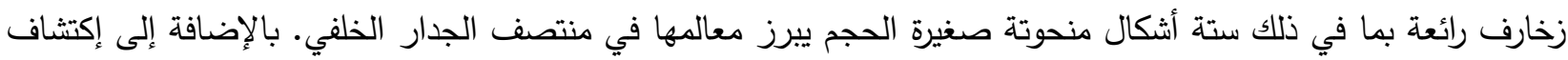
عامود لحجرة جنائزية أخرى والكشف عن العديد من الغرف المنهوبة التي لم تسفر عن إكتشافات قيمة. كما تبين أن جداراً كبيراً من الطوب اللبن، كان قد تم إكتشافه خلال الموسم الماضي، ينتمي إلى الجدار الخارجي ومدخل لمقبرة ضخمة لم يتم تحديد إسم مالكها بعد.

أسفر مسح تصويري قام به فريق من جامعة العلوم التطبيقية في ميلانو عن تقديم نموذج ثلاثي الأبعاد لموقع التتقيب (توجد نسخة منه على الموقع الالكتروني لهذا التقرير)، بالإضافة إلى العديد من النماذج ثلاثية الأبعاد للمقابر الأثرية (التي تم إعدادها

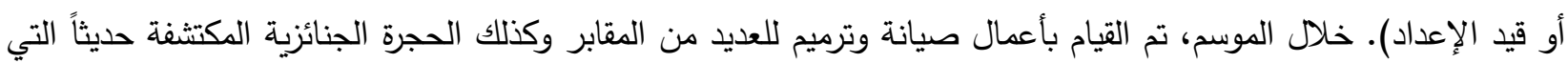
تعود إلى حقبة الرعامسة. 
In 1975, the National Museum of Antiquities in Leiden, together with the Egypt Exploration Society, London, endeavoured to find the tomb of Maya and Merit, whose monumental limestone statues had been in the Leiden museum since $1829 .{ }^{1}$ As usual for artefacts entering the museum via the art trade, the find spot of the statues was not known. However, it turned out that a few years later Carl Richard Lepsius had seen and documented the courtyard of the tomb and published some of its reliefs and a map of the location of the tomb of Maya and Merit. $^{2}$ This map offered the starting point for the quest for the tomb of Maya and Merit. Over the past 44 years, the Leiden expedition has achieved outstanding results. Not only did it succeed in discovering the tomb of Maya and Merit, in 1986, but over the years it excavated, studied and published another eleven monumental tombs and many smaller ones. ${ }^{3}$ In 1999, the Egypt Exploration Society left the joint project and Leiden University was found as a new partner. ${ }^{4}$ In 2015, the Museo Egizio in Turin joined the project as yet another partner. The excavations are currently directed by Christian Greco and Lara Weiss, with Paolo Del Vesco acting as their deputy. In this relatively new cooperation, the two museums are continuing in the long and successful tradition of the Leiden excavations in Saqqara, but they are also opening new perspectives and broadening the research scope. The area under investigation was in use continuously from the Early Dynastic to the Byzantine period, and human activity can be traced until today. Therefore, in 2018 more emphasis was put on excavating and studying all phases of the history of the site, regarded as a palimpsest on which human activity and nature left complex and intertwined traces for thousands of years.

\section{A cultural geography of Saqqara}

The Leiden-Turin fieldwork at Saqqara is not only supported by the two museums - the National Museum of Antiquities in Leiden and the Museo Egizio in Turin - but also funded by the Netherlands Organisation for Scientific Research (NWO). Thanks to a large NWO grant, two fulltime postdoctoral research fellows hosted at the Leiden Institute of Area Studies, Nico Staring and Huw Twiston Davies, are presently working on a new project entitled "The
Walking Dead at Saqqara: The Making of a Cultural Geography", ${ }^{5}$ under the supervision of Lara Weiss. The point of departure of their research is the acknowledgement that ancient Egyptian religion was subject to constant change. ${ }^{6}$ In other words, the material evidence at Saqqara (as indeed at all archaeological sites) is the result of individuals and groups continuously shaping their environment, and whose activities were shaped, in turn, by their ever-changing environment. ${ }^{7}$ Reconstructing the cultural geography of these material remains involves (1) correlating finds to their wider environment, e.g. to earlier and contemporary structures, access routes, and traces of later reuse; (2) tracing changing transmission processes of tomb decoration and texts; and (3) pinning down the variety of religious practices performed during and after burials. Cultural geography thus helps to detect the manifold negotiation processes that shaped the larger Saqqara area. ${ }^{8}$ The choice of the definition "cultural geography" as opposed to "sacred geography" or "religious geography" is intended to avoid the presumption that all individual and group actions were religiously motivated. For example, the building of a large and beautiful tomb could provide status to the living and the opportunity to demonstrate their upper-class taste and knowledge of required ritual. ${ }^{9}$ The broader focus of the current fieldwork is thus the perfect complement to the cultural geography approach of the "Walking Dead" project.

\section{The 2018 fieldwork season}

In 2018, the Leiden-Turin joint mission continued the excavation in the northern sector of its concession area, covering ten grid squares (V-W/80-85, approx. $250 \mathrm{sqm}$ ) situated immediately to the north of the large Eighteenth Dynasty tomb of Maya (Fig. 1). ${ }^{10}$ The fieldwork was carried out in close collaboration with Dr Sabry Farag (Director of Saqqara and Abusir), Dr Hany el-Tayeb (Director of Saqqara South) and Mohamed Hendawi (Chief Inspector) and was supervised in the field by Abdou Othman (inspector). The expedition is very grateful to $\mathrm{Dr}$ Khaled el-Anany (Minister of Antiquities), Dr Mustafa Waziri (Secretary General of the Supreme Council of Antiquities), Dr Mohammed Ismail (former Director of the Foreign Missions and Permanent Commit- 
tees Office of the Department for Foreign Missions), and to the members of the Permanent Committee of the Supreme Council of Antiquities, for permissions, advice, and assistance. We also acknowledge the valuable collaboration of SCA restorers Dr Ashraf Fahmi and Ismail Raghab. Last, but definitely not least, we would like to deeply thank the ever-helpful Salah El-
Deen Hasabalaa, our dear friend, chef, housekeeper and much more, Atef Sayed Ramadan, and the more than thirty diggers, shovellers, basket-carriers, water-carriers and pottery assistants, ${ }^{11}$ without whose work nothing could have been done or found in this or any season.

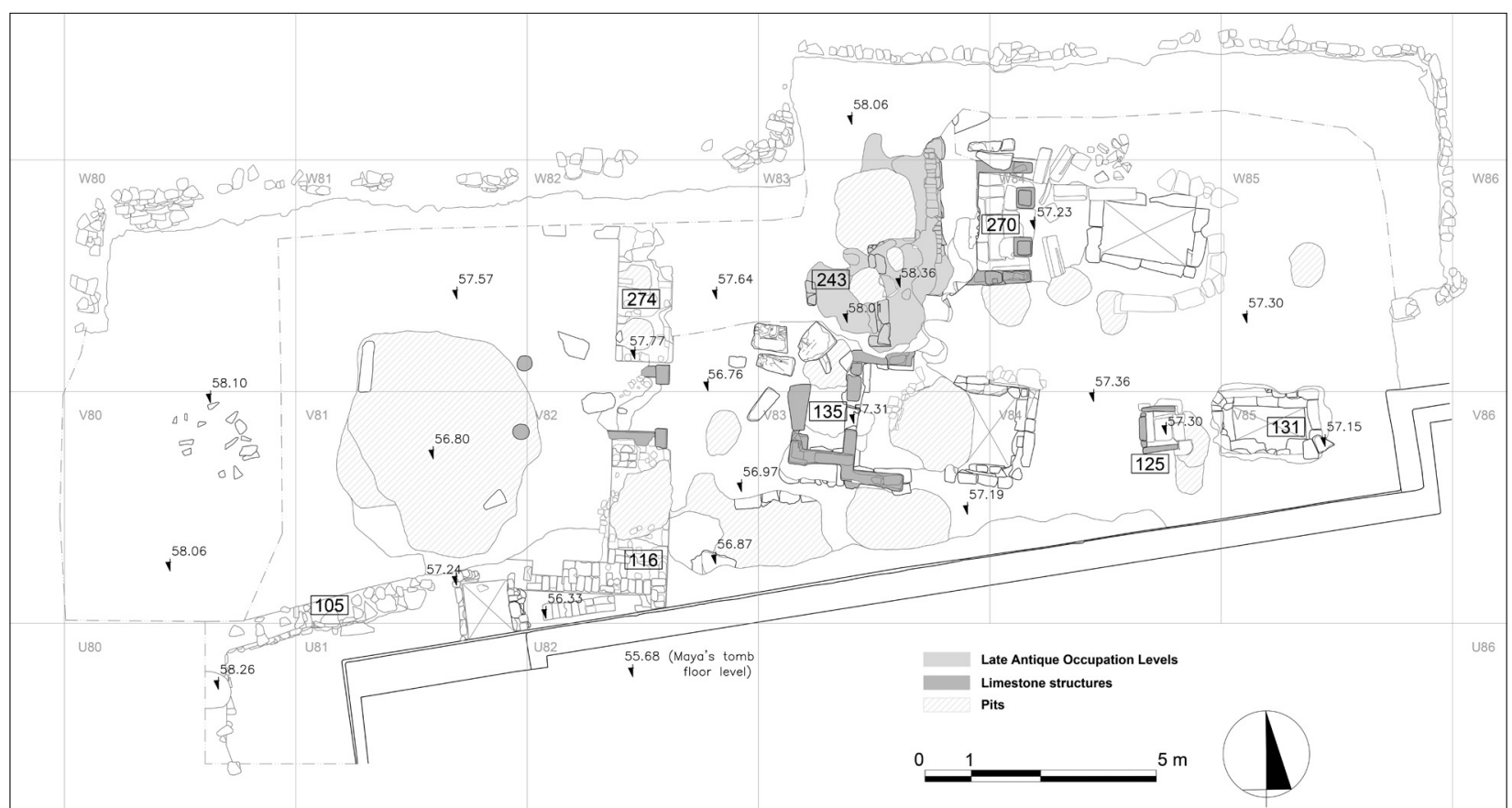

Fig. 1: General plan of the excavation area, based on orthographic photos by the 3D Survey Group. In square W83 are the remains of the Late Antique occupation layers, in squares V/W-83/84 the three Ramesside funerary chapels with their respective shafts, and in squares V/W 82 the remains of the mud-brick pylon entrance of an earlier tomb. All the main robbery pits are also indicated by means of shading. By Paolo Del Vesco/Leiden-Turin Expedition to Saqqara.

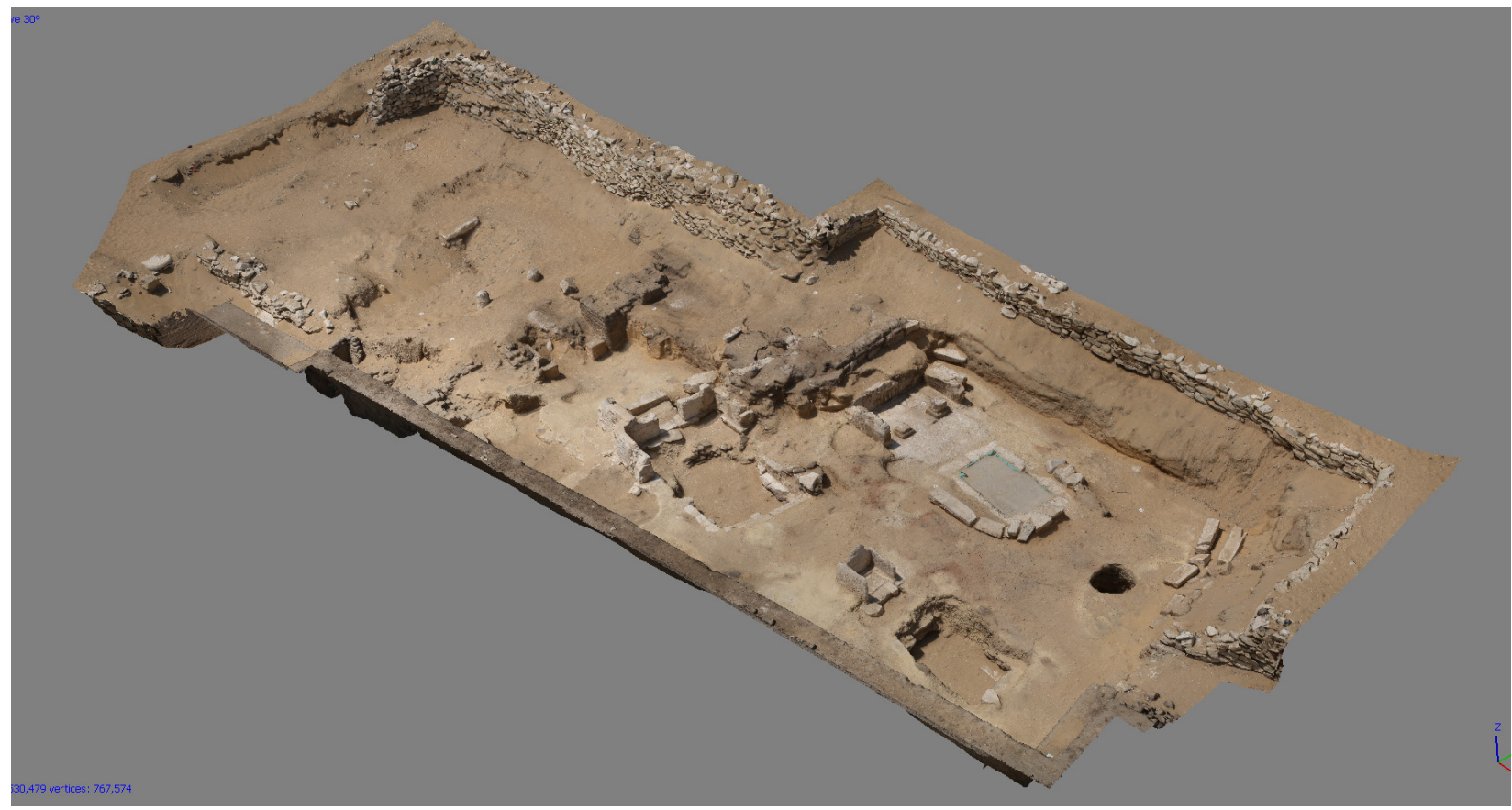

Fig. 2: Photogrammetric model of the entire excavation area by the 3D Survey Group of the Politecnico di Milano. For the full explorable version, go to the web version of this article. 


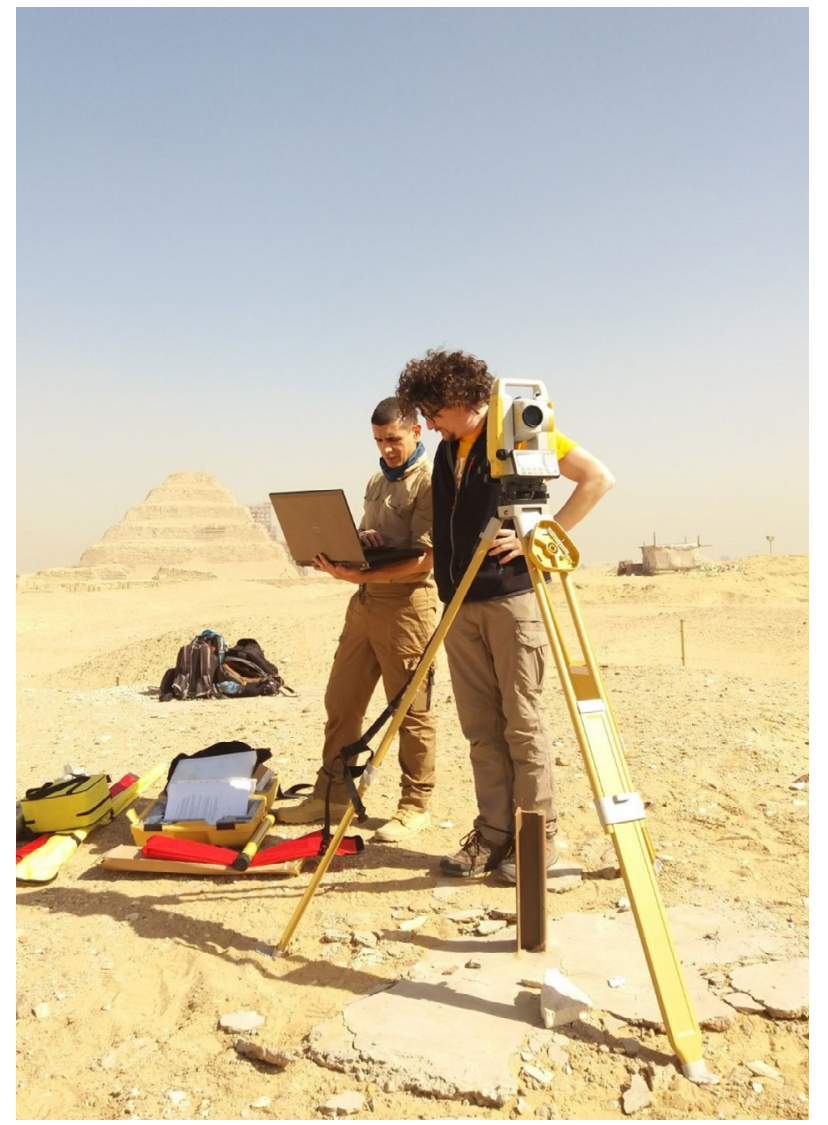

Fig. 3: Francesco Fassi and Alessandro Mandelli of the 3D Survey Group checking the reference grid of the excavation area. Photo by Leiden-Turin Expedition to Saqqara.

\section{The photogrammetric survey}

In 2018, the Dutch-Italian mission to Saqqara decided to use digital imaging to document the mission's activities, in collaboration with the 3D Survey Group, Department ABC, Politecnico di Milano. ${ }^{12}$ During the season, the survey team worked on several fronts: the general topography, the previously excavated tombs in the area, and the documentation of the ongoing excavation (Fig. 2).

After checking the topographic network using a Topcon Total Station (Fig. 3), the team focused on the area under investigation. Throughout the season, the team recorded in 3D over 100 contexts as they were progressively exposed; at regular intervals, general surveys of the entire area were also performed.

The photogrammetric survey of the undulating surface of the area was carried out by means of a DSLR Canon 5D MKIII, endowed with a 22 Mpix full frame CMOS sensor, using either a $35 \mathrm{~mm}$ or a $20 \mathrm{~mm}$ lens. For the survey of the funerary shaft, an $8 \mathrm{~mm}$ equisolid fisheye lens was employed for the interior ${ }^{13}$ and a $20 \mathrm{~mm}$ lens for the exterior. The overall accu-

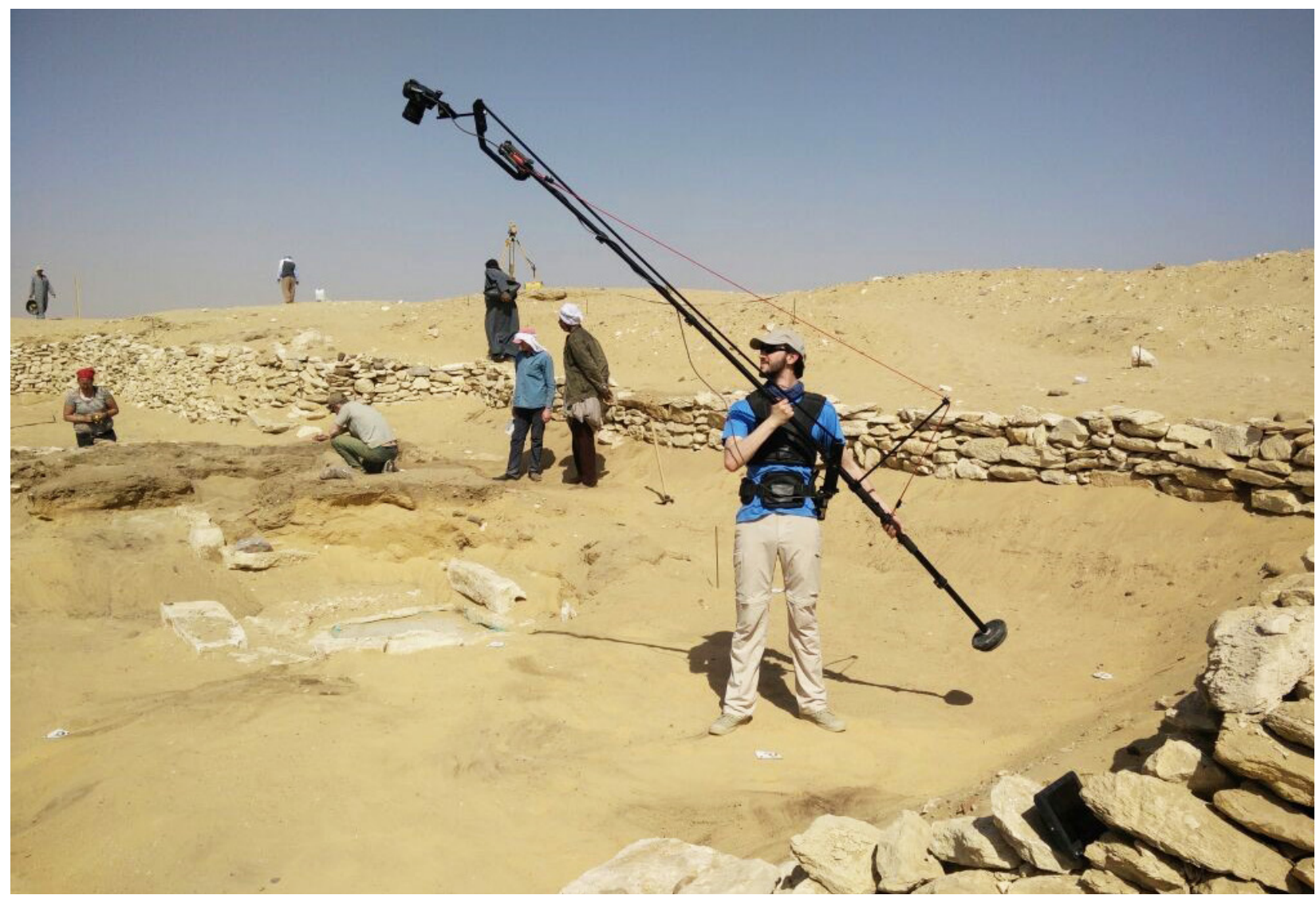

Fig. 4: Luca Perfetti of the 3D Survey Group documenting the excavation by means of a photographic crane. Photo by LeidenTurin Expedition to Saqqara. 
racy of the $3 \mathrm{D}$ models ranges from $0.1 \mathrm{~mm}$ in the decorated Ramesside chapel (no. 270) to $1 \mathrm{~cm}$ in the general orthophotos, taken with the aid of a photographic crane (Fig. 4).

During this time, the team completed the survey of the tombs of Maya and Tia (both the general geometry and the reliefs), started the survey of those of Horemheb and Meryneith, and completed the survey of the reliefs of the latter. The geometry of the tombs was recorded with an accuracy of $1 \mathrm{~cm}$, with peaks of $0.2 \mathrm{~mm}$ for the reliefs of Meryneith and an average accuracy of $0.5 \mathrm{~mm}$. The ongoing post-fieldwork processing of these data has so far yielded 3D models of the tombs of Maya and Tia, generously funded by the Friends of Saqqara Foundation, Leiden. In addition, two small objects were also surveyed in 3D, namely, a pilgrim flask and a small undecorated dish (SAK18C.1089 and SAK18C.1011).

CR

\section{Traces of Late Antique occupation}

In 2017, during the first season of excavation in the new area of the concession to the north of the tomb of Maya, the nature of the high ground located here had been clarified. ${ }^{14}$ A sloping compact mud crust, identified as the original surface of the high ground back in the 1980s, was covered by heaps of limestone chips and modern mud-brick fragments, which had originated from the restoration activity carried out on Maya's tomb after its discovery, by high deposits of debris dumped here during the excavation of other nearby tombs in the then Anglo-Dutch concession, and by wind-blown sand deposits. Beneath the compact mud surface instead, various deposits of loose debris attest to the uncontrolled and largely undocumented digging of the area, mainly in the early nineteenth century. These deposits appear to rest directly on top of the scanty remains of an abandonment phase of occupation levels which have been dated, on the basis of a preliminary analysis of the pottery, to Late Antiquity. ${ }^{15}$

Despite the strong erosion that has affected these levels, preserved in most cases only to an average height of $20-25 \mathrm{~cm}$, a number of stratified activities could be identified. The remains of floor levels, trash deposits, plastered installations, stone foundations and very worn mud-brick walls (Fig. 5) allowed us to recognise at least three different phases of occu-

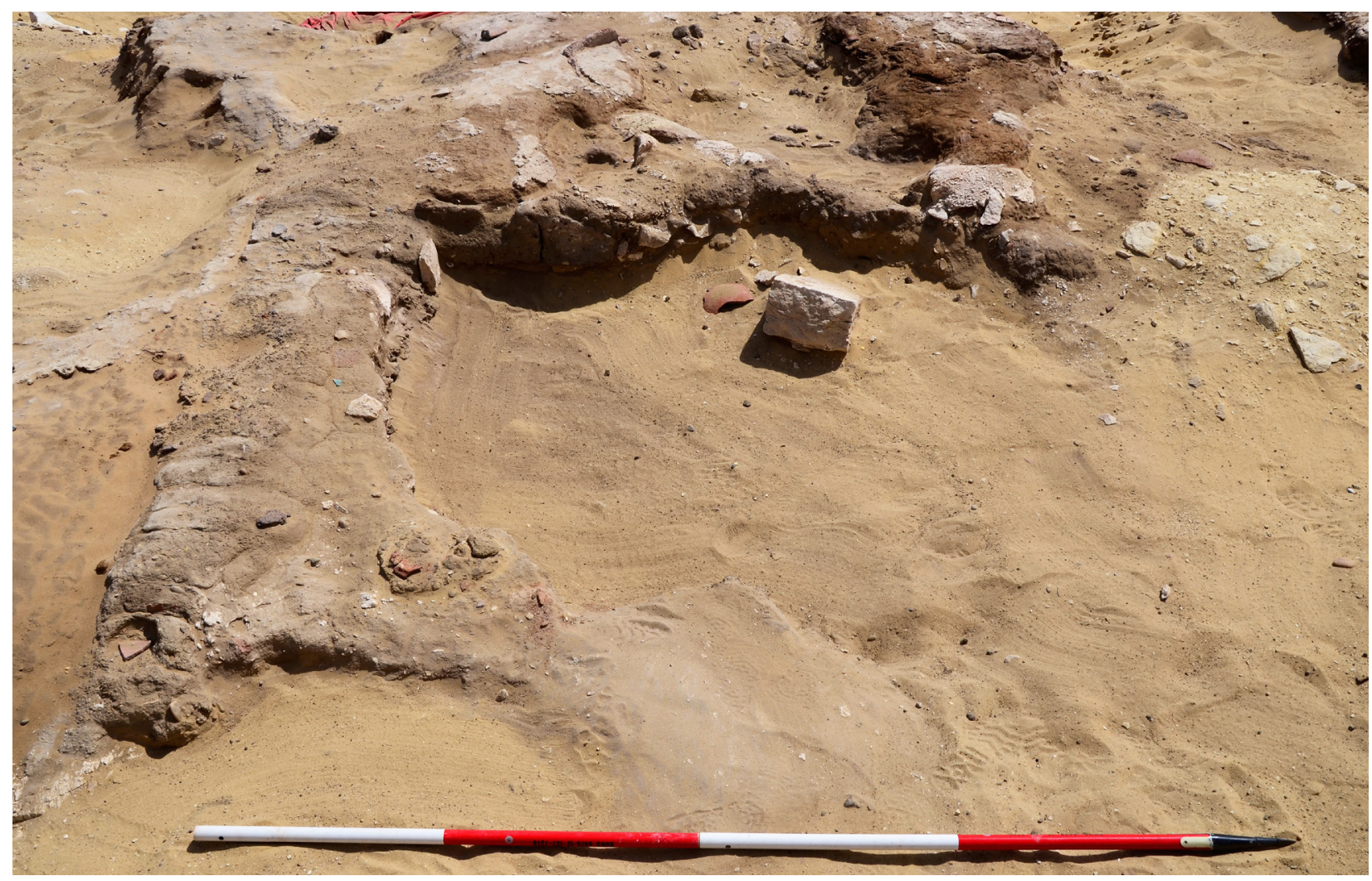

Fig. 5: Remains of mud-brick walls and plastered surfaces of the Late Antique occupation levels, badly damaged by more recent digging activity. Photo by Paolo Del Vesco/Leiden-Turin Expedition to Saqqara. 


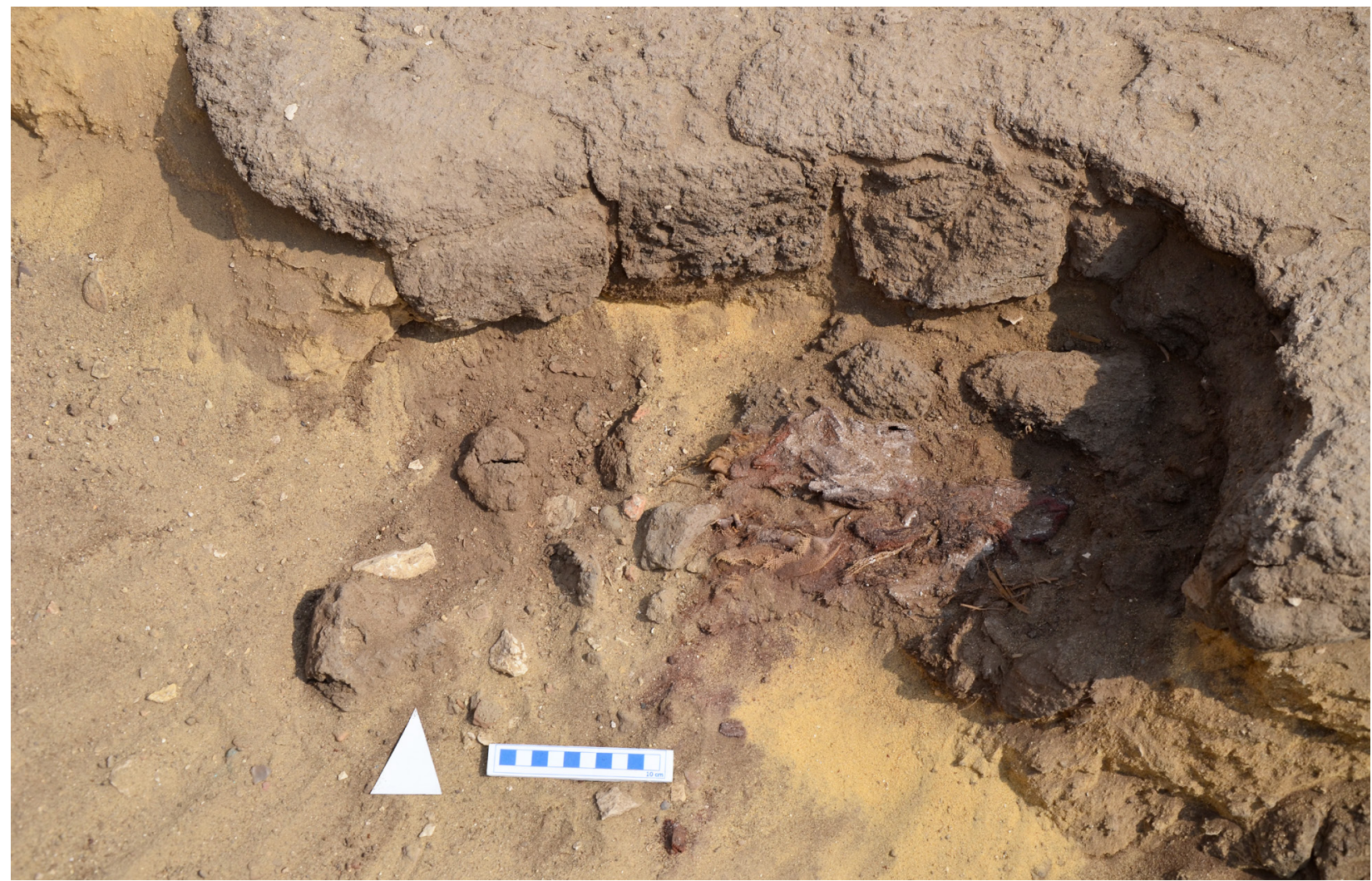

Fig. 6: Child burial no. 1 (context 249), dug in the corner of a mud-floored room. The south and west sides of the small burial pit were destroyed by a later and much larger robbery pit. Photo by Paolo Del Vesco/Leiden-Turin Expedition to Saqqara.

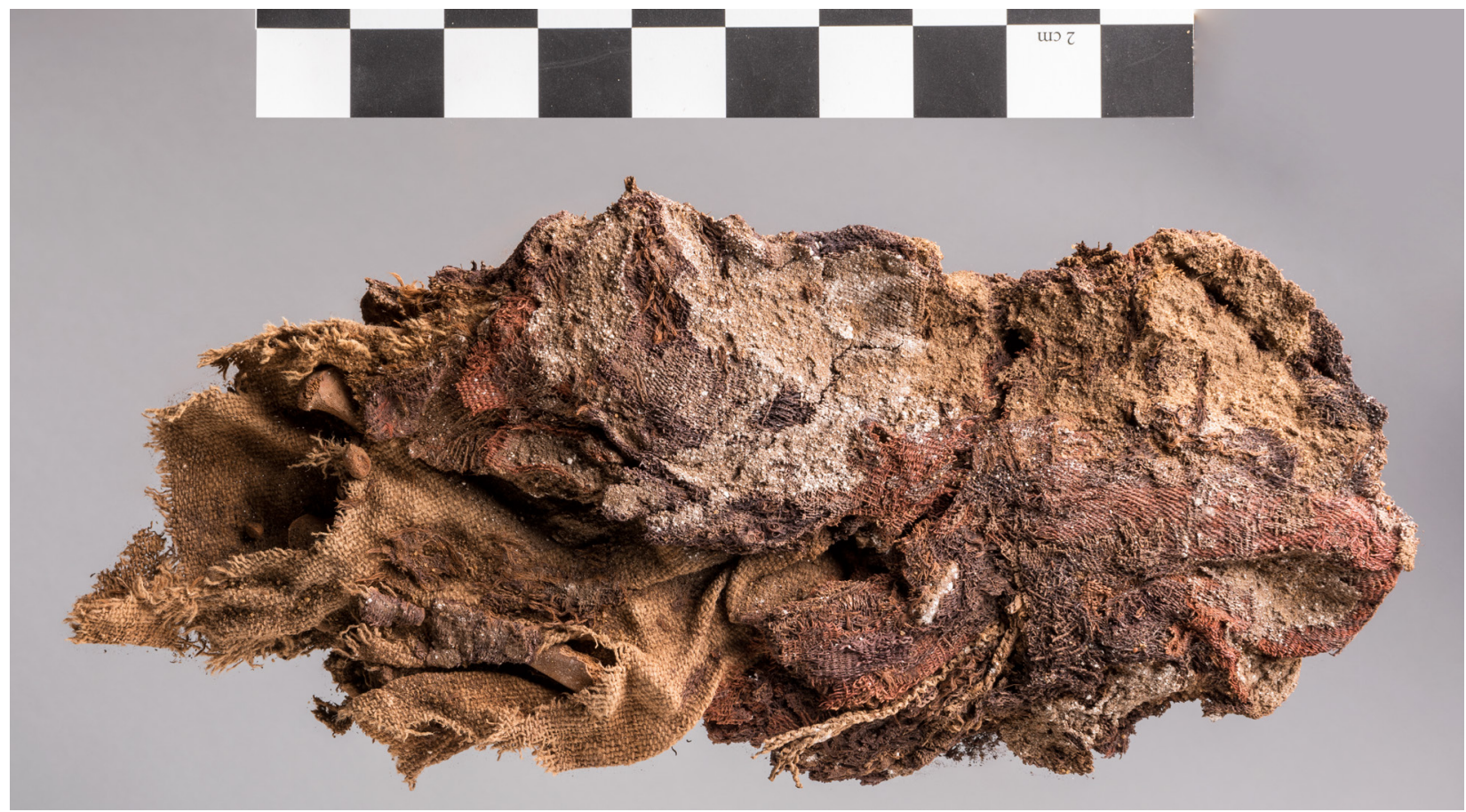

Fig. 7: The textile wrapping from child burial no. 1 (context 249) apparently had a red-coloured hem and was tied with a very thin string. Photo by Nicola Dell'Aquila/Leiden-Turin Expedition to Saqqara.

pation. In many instances, though, the connections between the floors and structures across the excavation area were lost due to the later extensive pitting. However, careful documentation of the stratigraphy and state-of-the-art digital recording of the excavation allowed the missing links to be virtually restored during the post-excavation processing work. A small pit, approximately $50 \times 30 \mathrm{~cm}$, its sides and 

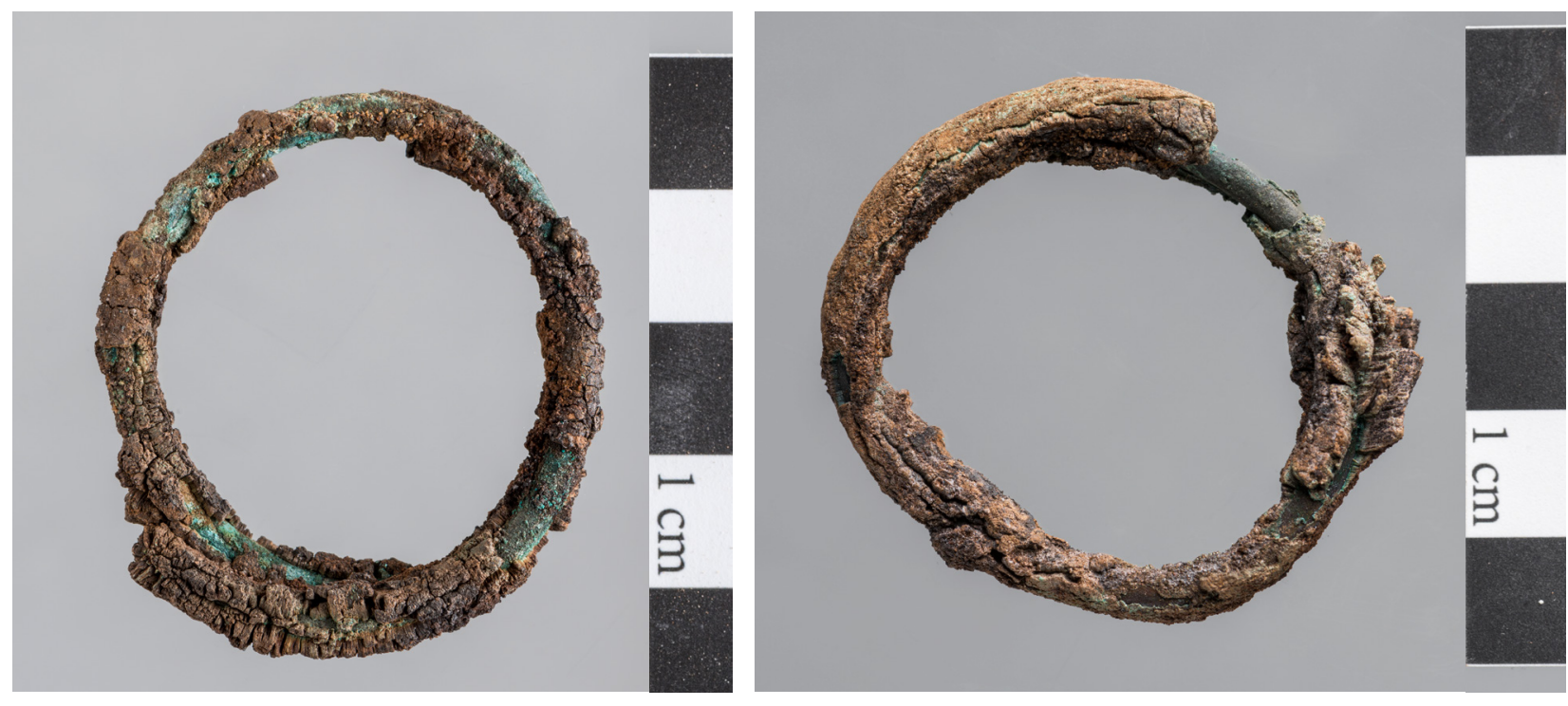

Fig. 8: Bronze bracelets, SAK18F.73 and SAK18F.87, found in child burial context 275. Photos by Nicola Dell'Aquila/LeidenTurin Expedition to Saqqara.

bottom carefully lined with mud lumps (Fig. 6), was dug in the mud floor of a room (context 243), and contained burial no. 1 (context 249 ) of a young child wrapped in a linen cloth (Fig. 7).

A second child, similarly wrapped in linen, was found in a nearby burial (see context 275 and Fig. 32 in the preliminary analysis of human remains below). It was still adorned with two simple bronze bracelets (Fig. 8), one on each arm. ${ }^{16}$ This child's skeletal remains will be further studied during the 2019 season.

The mud-brick walls pertaining to these Late Antique occupation levels are built on rather irregular stone foundations, which appear to be made of re-used blocks (Fig. 9). The blocks were most likely sourced on the spot from the still standing or collapsed walls of the New Kingdom funerary structures (see below), which lay only some $10-20 \mathrm{~cm}$ under the level of the first phase of Late Antique floors (58.01 $\mathrm{m}$ in the local reference system).

Just next to the remains of one of the walls, a trash pit was identified and excavated. From this $50 \mathrm{~cm}$ deep pit, which was probably connected with production activities, various discarded tools were retrieved, including a whetstone, a polishing stone and several flint knives. Equally interesting was the identification of a storage installation (Fig. 10): a thick-walled storage vessel was apparently used for some time and later buried, sealed by a layer of plaster and turned into a smooth working surface with

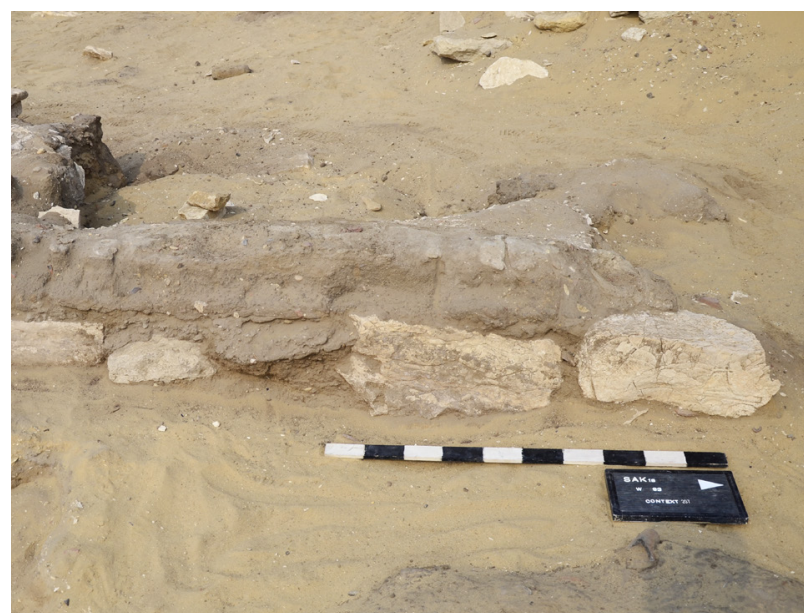

Fig. 9: Context 207. The reused block at the right end of the stone foundation of the wall shows traces of the base of an offering stand from the decoration of a tomb or chapel. Photo by Nico Staring/Leiden-Turin Expedition to Saqqara.

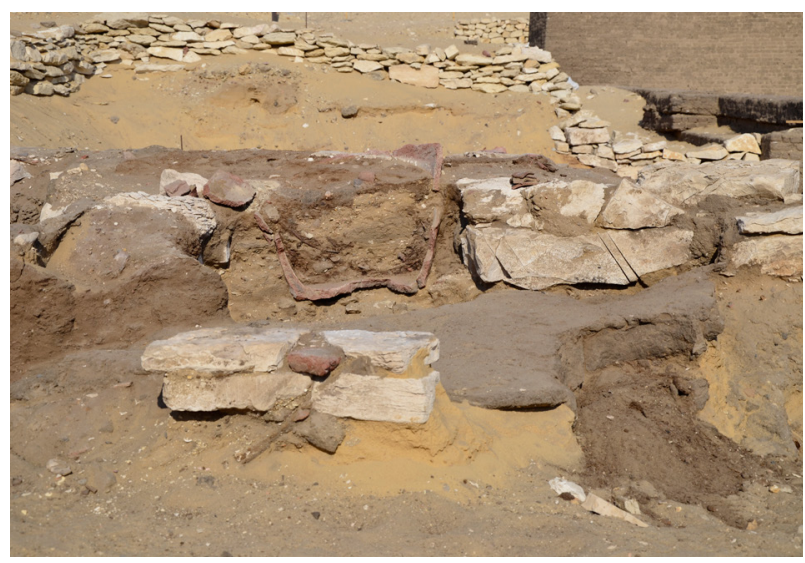

Fig.10: A storage installation set into previous deposits and structures, later filled up and used as a plastered surface; it was subsequently cut by a pit. Photo by Paolo Del Vesco/ Leiden-Turin Expedition to Saqqara. 


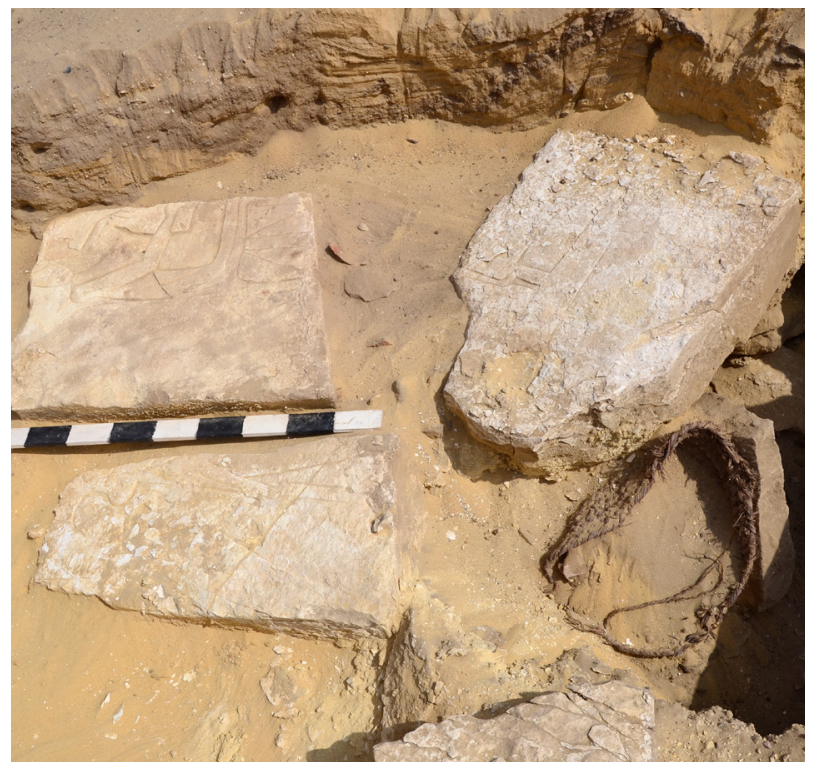

Fig. 11: Dismantled blocks from chapel 135 and the palm leaf basket left by a nineteenth century digger at the bottom of his robbery pit. Photo by Paolo Del Vesco/Leiden-Turin Expedition to Saqqara.

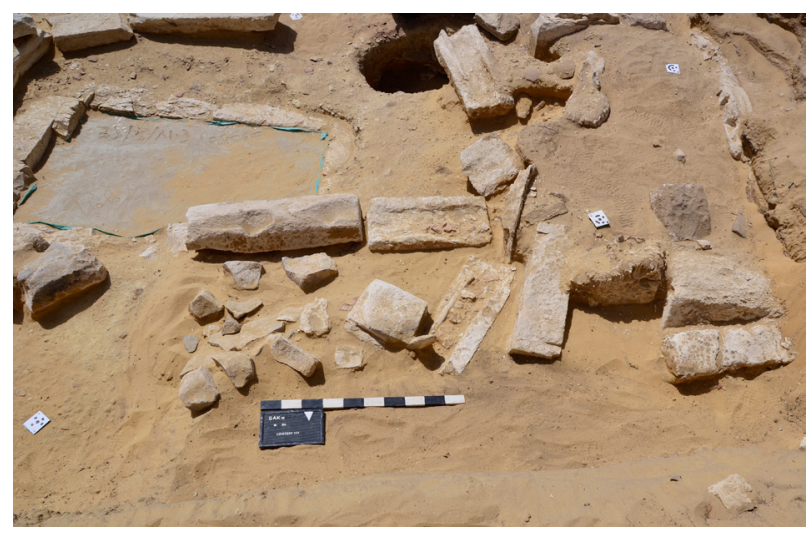

Fig. 12: Scattered stone blocks (context 268) from the abandonment and destruction of chapel 270, covered by the wind-blown sand deposit. Photo by Nico Staring/LeidenTurin Expedition to Saqqara.

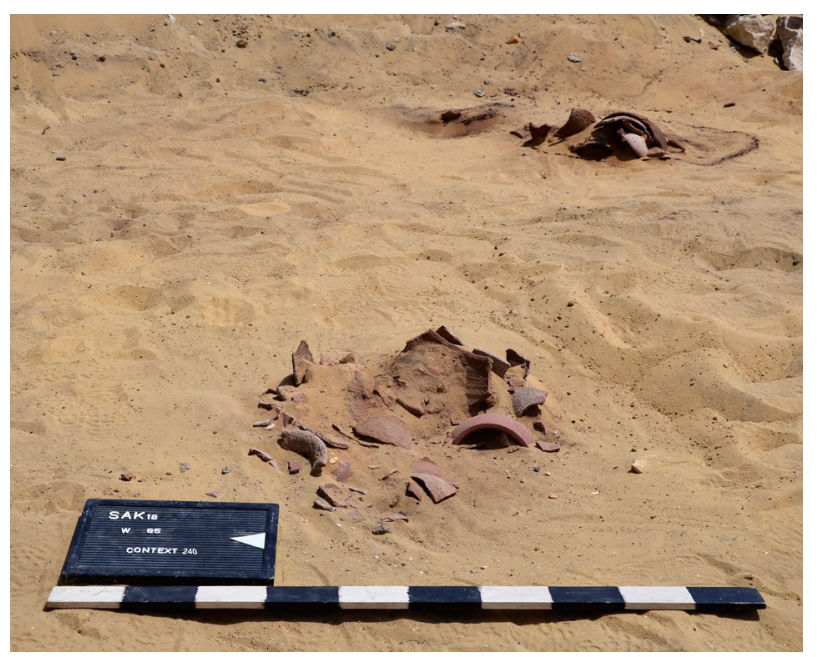

Fig. 13: Two so-called "embalmers' caches" found in square W85. The one in the background (context 241) also yielded a nice example of a pilgrim flask (SAK18C.1089). Photo by Nico Staring/Leiden-Turin Expedition to Saqqara. raised edges. This installation was eventually cut by a later pit.

\section{Abandonment and reuse of the area}

As already mentioned, the remains of Late Antique occupation levels were badly damaged by a number of later pits probably dug in search for antiquities during the nineteenth century. ${ }^{17}$ One such robbery pit cut into the north-west corner of chapel 135, causing the dismantling of its northern wall and stone-paved floor. The digger broke off a few centimetres below the wall and left his palm leaf basket - the ancestor of the modern tyre rubber baskets so frequently used in Egyptian archaeology - at the bottom of the pit (Fig. 11). ${ }^{18}$

Although destructive, these robbery pits allow archaeologists a sneak preview, albeit limited and partial, of the underlying stratigraphic sequence before extending the excavation horizontally. Spread over the entire area, but varying in height between 20 and $50 \mathrm{~cm}$, a deposit of fine wind-blown sand separates the abandonment level of the Ramesside funerary chapels from the earlier floors of the Late Antique occupation layers.

This sandy deposit thus covers the displaced stone blocks deriving from the collapse and dismantling of the Ramesside chapels (Fig. 12). It also contained some very simple interments (see for instance burials no. 2 and no. 3 in the "Preliminary Analysis of the Human Remains" paragraph below), which were later heavily damaged by the plunderers' activity, so abundantly documented in the area. As in the 2017 season, the wind-blown sand deposit also yielded numerous small pits containing pottery sherds most likely originating from vessels used during some sort of embalming procedure. Notably, during the 2018 season six such "embalmers' caches", as they are usually called, were recorded and excavated in squares W84 and W85 (Fig. 13). They appear to date to the fifth century BCE.

The vessels and sherds collected from these caches (see the preliminary pottery report below) complement the series of bowls, cups and bottles from the seven "embalmers' caches" excavated during the 2017 season. In addition to the usual vessels, the new caches also yielded a variety of interesting small finds, such as linen natron bags, flint knives and a 


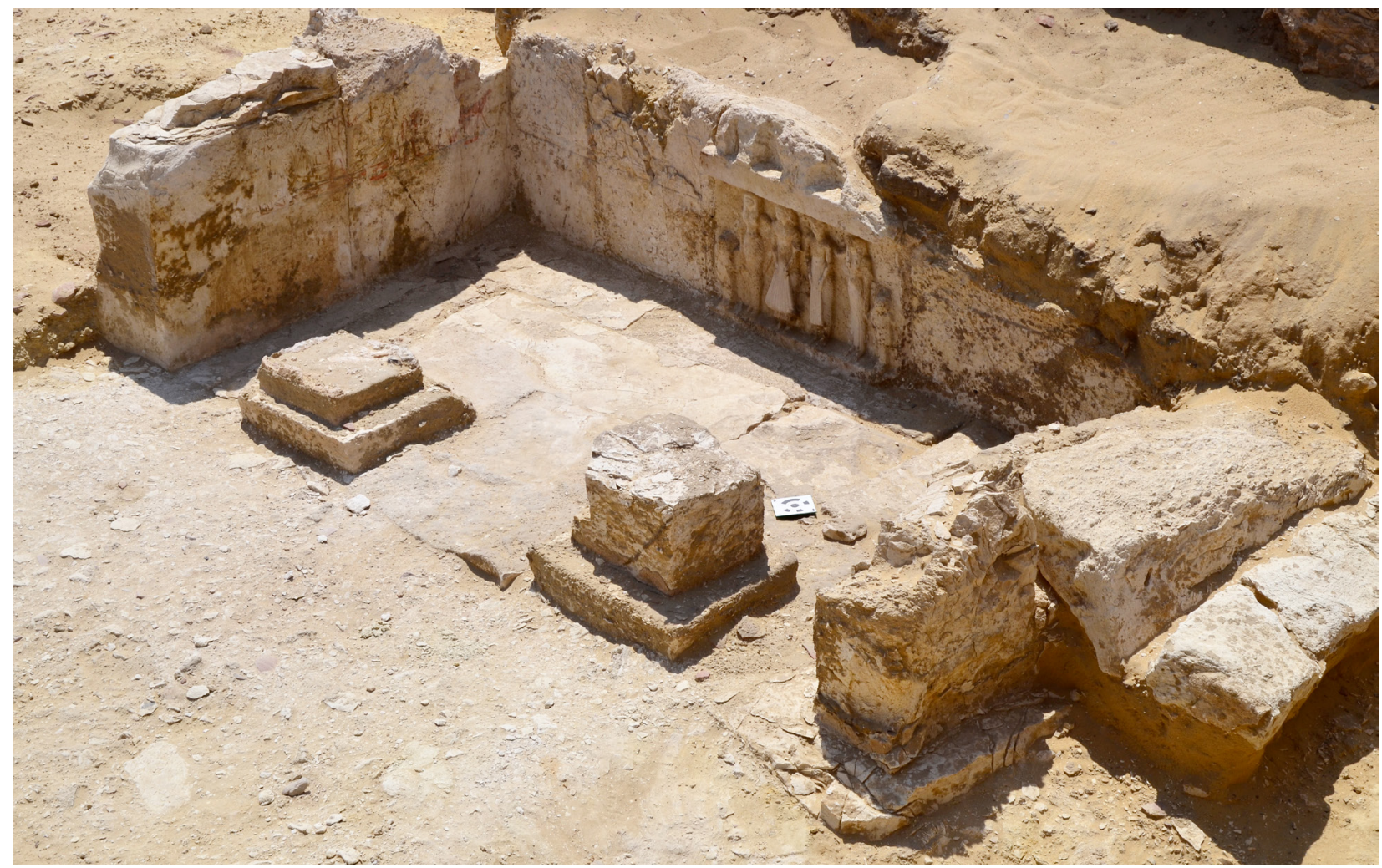

Fig. 14: The new chapel (context 270) seen from the north-east. Photo by Leiden-Turin Expedition to Saqqara.

few marl clay cups bearing hieratic labels (see Fig. 29 below). These labels, currently under study, contain the usual mentions of ingredients probably used during the preparation of the corpse, such as "the concoction for the cavity" ( $t$ z phr.t $n h n$ ) or "resin/oil of [uncertain plant name]" (sfy $n[\ldots]+$ tree determinative), but also in one case an interesting and less common reference to "the concoction for embalming" ( $t$ s phr.t $w t y) .{ }^{19}$

\section{A new Ramesside chapel}

Underneath the wind-blown sand deposit, a compact rubble and mud tread surface was reached. It was tentatively dated, at least on a stratigraphic basis, to the late Ramesside or Third Intermediate periods. This compact mud surface or crust clearly covers the abandonment phases of the Ramesside funerary chapels and shafts. In the 2017 fieldwork season, two of these small limestone funerary structures (contexts 125 and 135), with associated tomb shafts, were identified. So far, their architectural layout and style of decoration corroborate a dating in the Ramesside period. ${ }^{20}$ The presence of these chapels suggests that we may be currently digging in an area between two or more larger tombs: the tomb of
Maya in the south might thus have a neighbouring structure of comparable size to the north.

In 2018, a new limestone Ramesside chapel (context under the Late Antique occupation levels mentioned above. This new structure clearly appeared to be related to a funerary shaft with a well-preserved limestone rim that had already been identified in 2017 . The chapel is about $140 \times 260 \mathrm{~cm}$, its floor is neatly paved with limestone blocks, and two sub-squared pillar bases (length of sides between 37 and $40 \mathrm{~cm}$ ) mark the facade. Fragments of the limestone cavetto cornice of a lintel and of the two pillars were found scattered in front of the chapel (Fig. 12). The chapel decoration is rather uncommon and the quality of the carving extraordinary. On the limestone slab at the centre of the western wall of the chapel are six figures carved in very high relief (almost as inthe-round statuettes), and are executed with an eye to great detail (Fig. 14, Fig. 15). Two couples stand side by side, the men in the middle, the women on the left and right, each with a child beside her. The hands of the embracing women are visible on the men's shoulders. The sleeves of the ladies' dresses nicely fill the spaces between each couple, hanging 


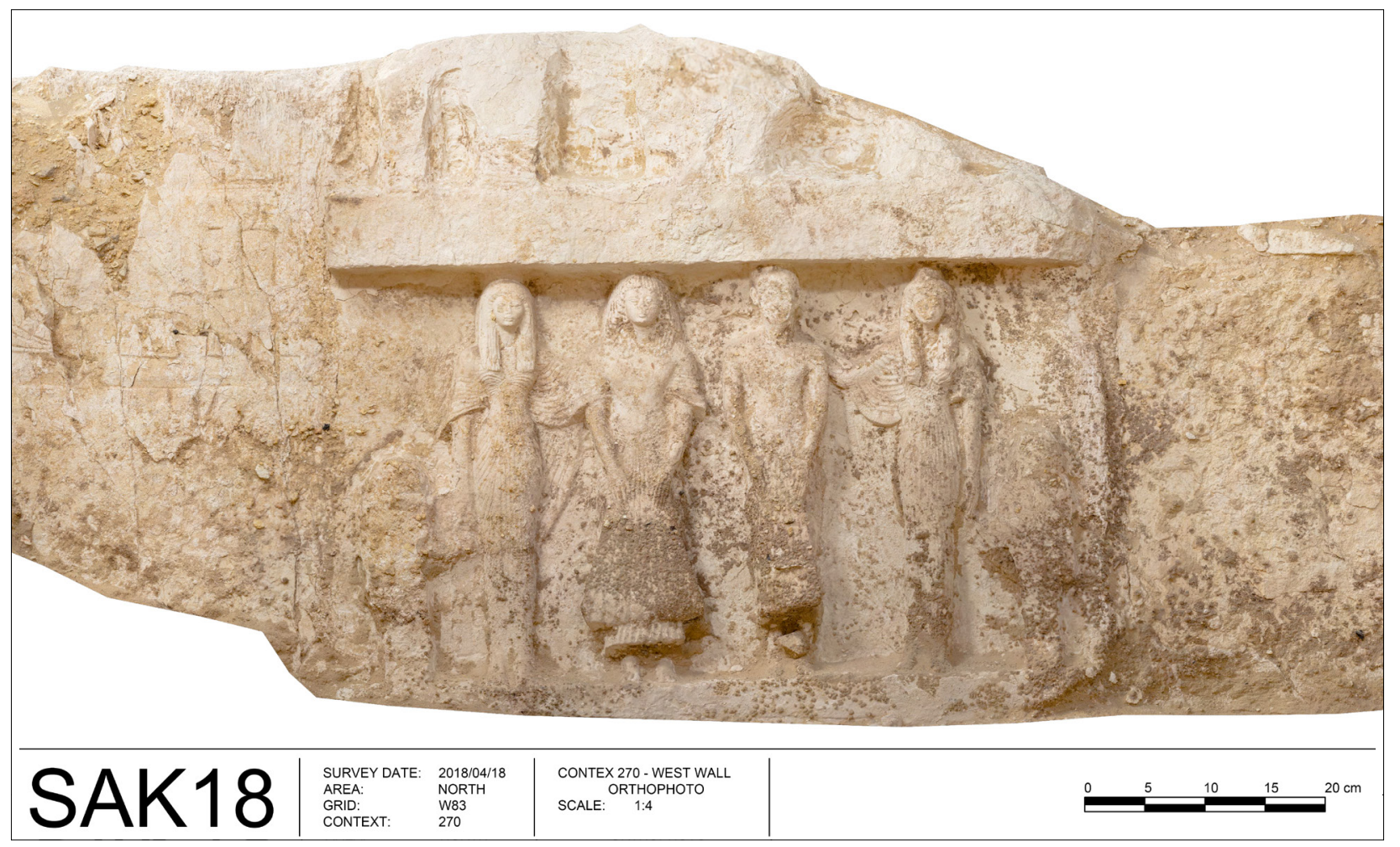

Fig. 15: Detail of the decoration of the limestone slab on the west wall of chapel 270. Orthophoto by 3D Survey Group, Politecnico di Milano/Leiden-Turin Expedition to Saqqara.

in a half-round shape. They wear the "dress with the shawl" that appears during the reign of Amenhotep III and comes back in fashion during the Ramesside period. ${ }^{21}$ Few parallels for such rounded sleeves are known from painted ${ }^{22}$ or relief ${ }^{23}$ tomb decoration, and as far as we know none from statuary. In group statues, when the figures sit far enough from each other that some space is left in-between, it is usually filled by the crossed arms of the figures. ${ }^{24}$

Alongside the women are the roughly cut outlines of two children. Although their carving was left unfinished, it appears that they were intended to hold hands with the women. No names or titles, unfortunately, are preserved in the chapel and the identity of the couples thus remains unknown. The man on the left wears a duplex wig and the typical Ramesside dress, a composite garment consisting of a long bag tunic with wide sleeves in combination with a wraparound sash kilt tied on the front; the man on the right has a bare shaven head and wears a long wraparound sash kilt tied on the front. The kilts of both men display a trapezoid front panel. The face of the male figure on the right is damaged, but his shaven head suggests that he is a priest, while the other man wears the garment befitting a high official. It is pos- sible that the two figures actually represent one and the same individual shown in two different roles. On the other hand, they may represent different members of the same family. ${ }^{25}$ The position of these figures at floor level is also interesting. No parallels are known to us for such chapel decoration in its original architectural context. Of course, larger statues are a known feature of tomb decoration, although they usually depict seated individuals. ${ }^{26}$

Close parallels in museum collections are for instance the stelae of Nebnetjeru with his wife and mother, and the upper part ${ }^{27}$ of one made for the two brothers Ptahmose and Mery-Ptah (Fig. 16), presumably from Saqqara and now in Leiden, as well as the stela of Bak and Tahery now in Berlin. ${ }^{28}$ The figures on these stelae are similarly carved as almost-in-the-round statuettes. They were possibly set up in small, single-room chapels with vaulted ceilings comparable to those found in the Teti Pyramid cemetery at Saqqara. ${ }^{29}$

A provenanced parallel that supports this interpretation is the naos of Menmaatreheb and his wife now in Boston. ${ }^{30}$ It was found by William Matthew Flinders Petrie in cemetery $G$ at Abydos standing in front of a large granite stela of Neferhotep, which 
was also at floor level. Such small naoi were relatively common, ${ }^{31}$ but often their original context is no longer known.

One of the best parallels for the decoration of the west wall of chapel 270 is perhaps stela Louvre C97, also from Abydos, which shows two standing couples underneath a row of sitting gods (Fig. 17). ${ }^{32}$ The individuals here represented are the high priest of Osiris, Wennefer with his wife Ty on the left, and his father Mery with his wife (and mother of Wennefer) Many on the right. ${ }^{33} \mathrm{~A}$ set of four cartouches on the top frame securely dates the stela to the reign of Ramses II. Moreover, in the panel above the standing figures four seated gods are represented: Hathor, Horus, Osiris and Isis. Although the panel above the standing figures in the newly-found chapel at Saqqara is badly damaged, remains of a frieze and traces of seated figures can be discerned. In the light of the Louvre parallel, the interpretation of the damaged decoration as a series of seated gods would be very likely. This interpretation is also supported by the discussion on the appearance of this type of statues that Eva Hofmann includes in her monumental study of Ramesside tombs in Thebes. Hofmann links the appearance of this type of statue to the growing significance of funerary chapels in relation to a combined worship of both the deceased and the gods. ${ }^{34}$ The south wall of chapel 270 also shows a very interesting scene, in which traces of vivid colours are still preserved (Fig. 18). Here the carved wall decoration in sunk relief is separated from the floor level by an undecorated dado, ca. $30 \mathrm{~cm}$ high. The scene and dado are divided, in their turn, by a very standard block frieze. The scene displays two bulls and three men pulling a sledge supporting a boat decorated with a banner. A priest walks besides the procession, which is proceeding westward. The boat is followed by a man and a woman and preceded by a woman; all three are in attitudes of mourning. The iconography suggests the scene may represent the funerary procession. It is odd, however, that no coffin or statue shrine is visible. ${ }^{35}$ On the adjoining west wall, several men approach what seems to be a tomb façade, supporting the idea of a funerary procession. Unfortunately, this part of the wall is highly damaged and not much can be made out. The northern part of the west wall and the north wall do not retain any

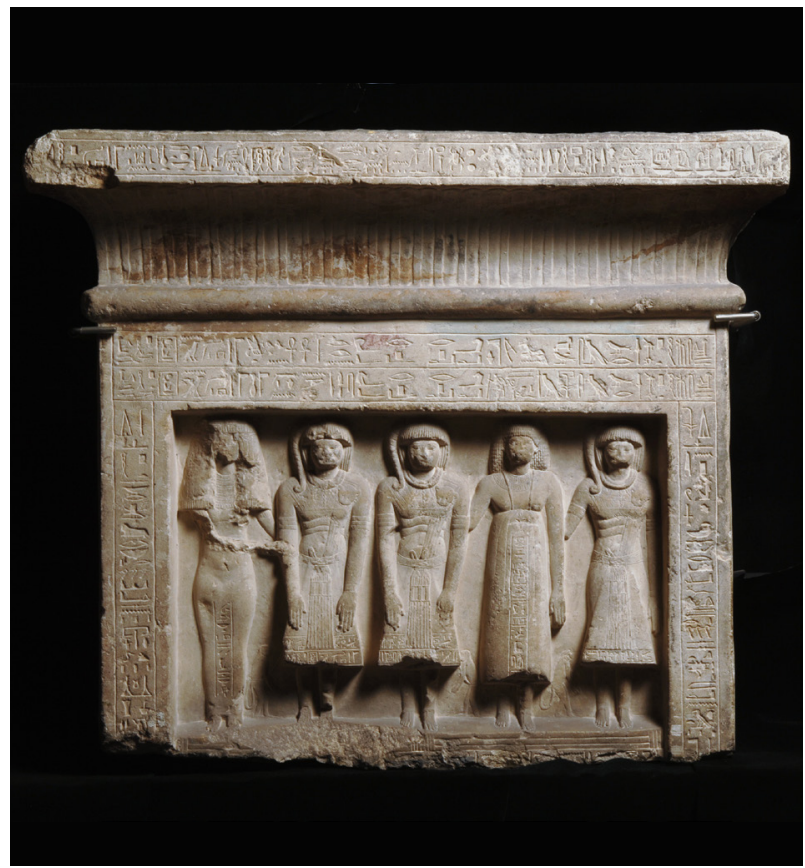

Fig. 16: Stela of Ptahmose and Mery-Ptah, probably Saqqara, Eighteenth Dynasty. Leiden inv. no. AP 11. Photo ๑Rijksmuseum van Oudheden, Leiden.

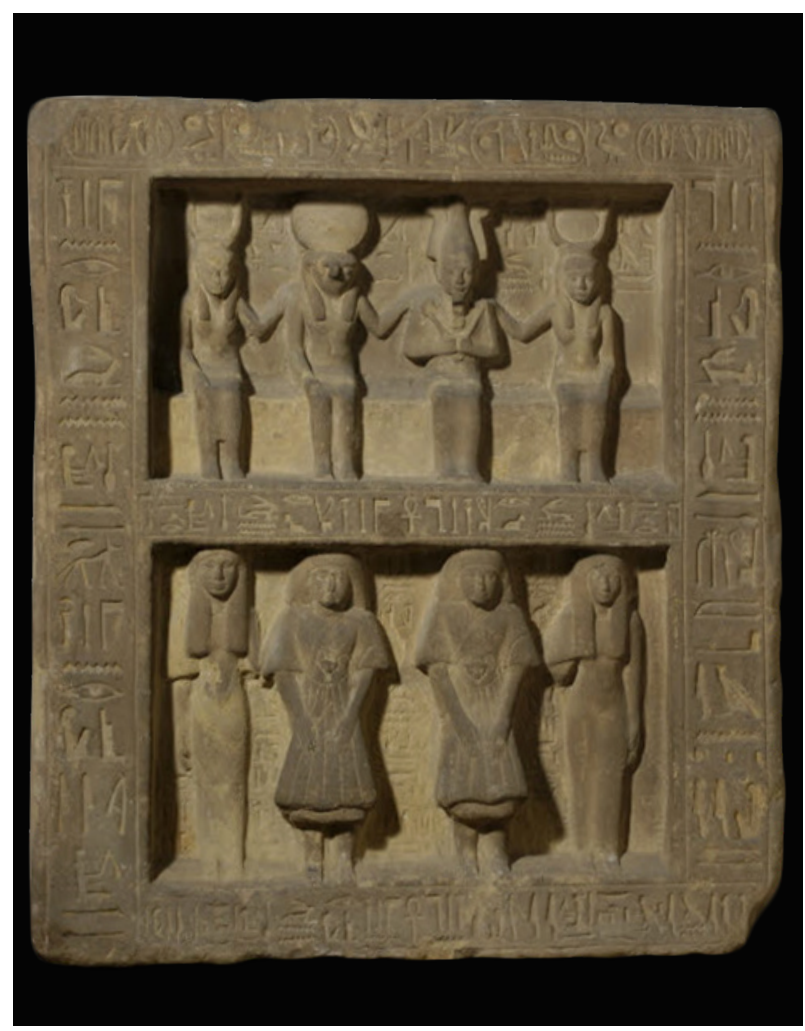

Fig. 17: Family stela of Wennefer. Sandstone, Abydos, Nineteenth Dynasty, reign of Ramses II. Louvre inv. no. C97. Photo @Musée du Louvre.

traces of decoration. As to the dating of the chapel, both stratigraphic and iconographic evidence seem to confirm a date in the Nineteenth Dynasty. 


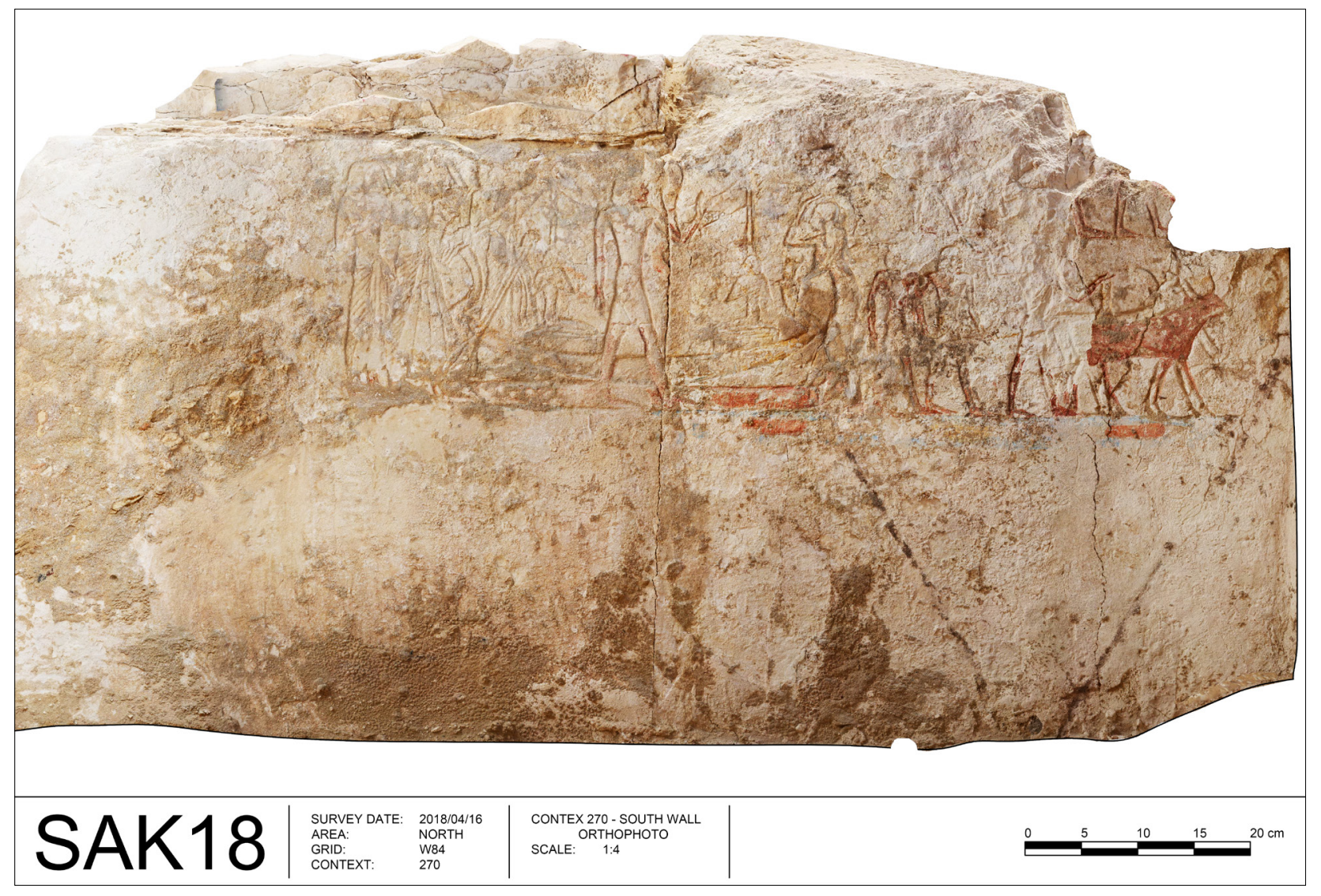

Fig. 18: Burial procession depicted on the southern wall of chapel 270. Orthophoto by the 3D Survey Group, Politecnico di Milano/Leiden-Turin Expedition to Saqqara.

\section{Excavation of the underground chambers of chapel 125}

The small chapel of Ramesside date (context 125) situated between Maya's north exterior wall and chapel 270 described above had already been uncovered in $2017 .{ }^{36}$ The associated tomb shaft, approximately $150 \times 70 \mathrm{~cm}$ wide, located to the east of this chapel was instead cleared of its loose filling during the last season. Its subterranean chambers could thus be partially explored. The upper part of the stone casing of the shaft had been almost completely removed from its north, west and south sides by later robbers, probably with the aim of re-using the blocks for their own buildings.

The bottom of the shaft lies at an elevation of $52.93 \mathrm{~m}, 4.37 \mathrm{~m}$ below the chapel's floor level. It gives access to three funerary chambers opening onto its west, south and east sides (Fig. 19, Fig. 20). So far, only the west room (A) and a 1 sq. $\mathrm{m}$ area of east room $C$ have been excavated. Two elongated limestone slabs found at the bottom of the shaft (one used to partially close the entrance to the southern side room B) were most likely part of the original

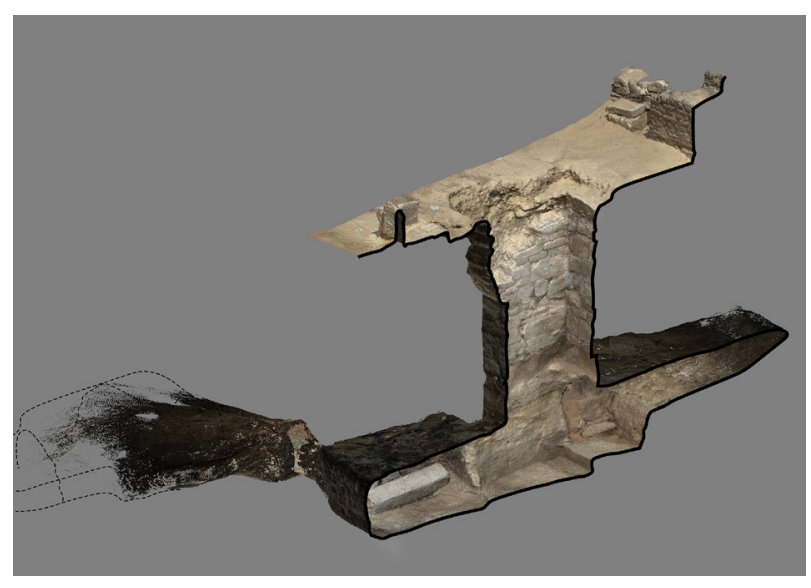

Fig. 19: Longitudinal section of shaft 131 and underground chambers seen from the south-west. The image also shows the small breach in the north-west corner of room $A$, connecting this room to other underground chambers, which are sketched with a dashed line. Image by 3D Survey Group, Politecnico di Milano/Leiden-Turin Expedition to Saqqara.

sealing of the mouth of the shaft.

One of the peculiarities of the shaft is a band of three courses of mud-bricks embedded in the stone casing halfway down. This feature, although rather rare, also occurs in a number of shafts explored during 

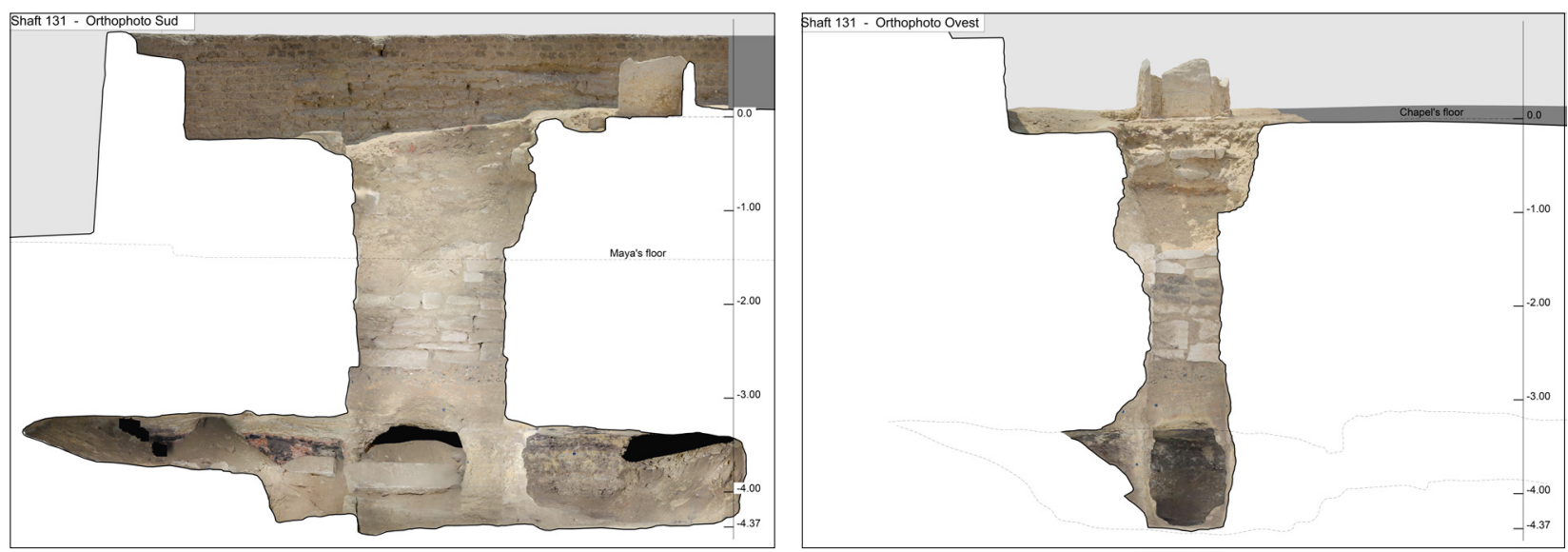

Fig. 20: On the left, east-west section of shaft 131, looking south, with indication of the floor level of Maya's tomb; on the right, south-north cross section looking west. Images by 3D Survey Group, Politecnico di Milano/Leiden-Turin Expedition to Saqqara.

past seasons in the area immediately to the south of the tomb of Horemheb. ${ }^{37}$ Interestingly, the mudbrick band in shaft 131 lies at an elevation ranging between 55.35 and $55.65 \mathrm{~m}$ (see Fig. 20, left), and appears thus to be at approximately the same level as the floor of the tomb of Maya, which oscillates between 55.68 and $55.84 \mathrm{~m}$ throughout the building, and theoretically corresponds to the Eighteenth Dynasty surface level of the necropolis. A possible explanation for the mud-brick band would then be that it originally crowned a much shallower shaft, already in use during the Eighteenth Dynasty, and was later re-adapted for a small chapel of Ramesside date.

Room A, which is cut rather irregularly, roughly measures $280 \times 210 \mathrm{~cm}$ and features an opening at its south-west corner which, although not yet freed from the debris encumbering it, seems to lead to another room. At the north-west corner, a narrow breakthrough, most likely dug by robbers, gives access to a larger chamber, which might well be connected to the funerary shaft of chapel 270.

Walls, ceiling and materials so far found in rooms A and $\mathrm{C}$ bear evident signs of combustion, which suggest that plundering activities took place here. The scanty finds so far retrieved are apparently relics of the use of the shaft in the Ramesside period and of its reuse in the Late Period and even in Late Antiquity.

\section{The entrance to a new monumental tomb}

The large mud-brick wall (context 116) abutting the northern exterior wall of the tomb of Maya, which had already been uncovered during the 2017 sea- son, ${ }^{38}$ turned out to be part of the exterior wall and pylon entrance of a new large tomb, whose owner's name has not been found yet. So far, only the northeast and south-east corners of the courtyard have been found, which allow us to calculate the internal width of the tomb at about 7 metres. The courtyard was filled with a high deposit of sand, which had been cut by a large robbery pit originating from very superficial layers, and therefore most likely made by modern plunderers. The remains of two limestone columns, with a diameter of about $30 \mathrm{~cm}$, emerge from the sandy deposit of the courtyard. They are perfectly aligned with the tomb entrance, and might thus be part of the original portico, a rather common feature in tombs of this size. The two massive walls of the pylon entrance (contexts 116 and 274) are 115 $\mathrm{cm}$ thick and made of mud-bricks measuring approximately $30 \times 16 \times 9 \mathrm{~cm}$, bonded by a $2.5-3 \mathrm{~cm}$ thick mortar. The reveals of the entrance are still partially dressed in stone slabs and slightly protruding door jambs framing a $100-120 \mathrm{~cm}$ wide passageway. The better preserved of the two walls, context 274 , still rises about $1 \mathrm{~m}$ above the level (56.80-57.00 $\mathrm{m}$ ca. in the local reference system) of the compact surface the small funerary chapels had been erected on, which thus dates to the Ramesside period (Fig. 21). The available evidence suggests, however, that these walls actually continue below this level, ${ }^{39}$ and that the original floor of the new tomb lies at a level close to that of the floor of Maya's tomb, some $110-130 \mathrm{~cm}$ lower than the level attained by our excavation so far. Although the "Ramesside" surface slopes slight- 


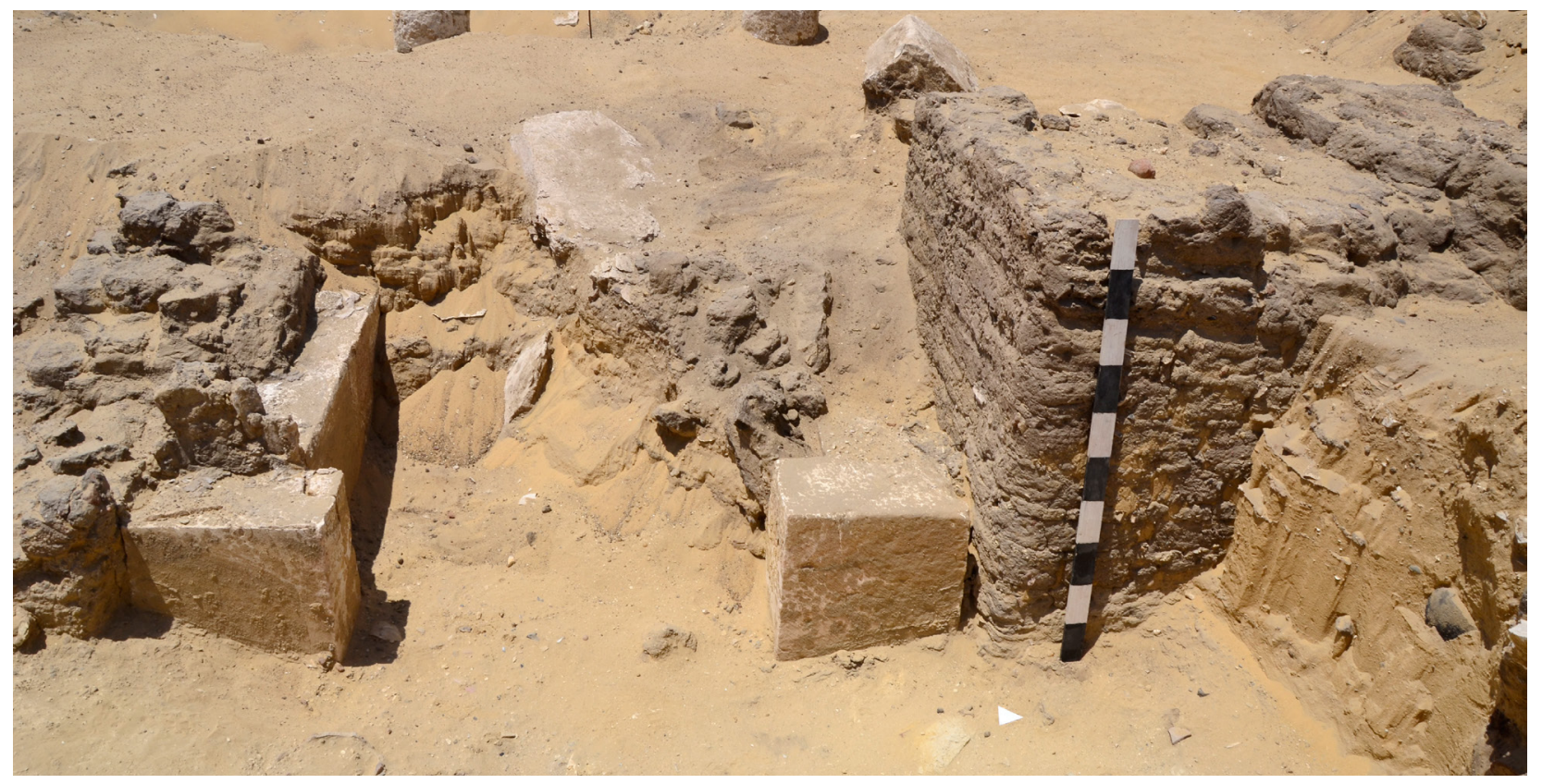

Fig. 21: The main entrance of the new tomb with part of the collapse of the large mud-brick wall still covering the original stone door jambs. Photo by Paolo Del Vesco/Leiden-Turin Expedition to Saqqara.

ly down towards the west, starting from the back wall of chapel 135 , it seems to continue into the new tomb, which indicates that the earlier funerary structure was still in use when the small chapels were being built and used, at least as a source for building material, stone blocks or reusable funerary equipment.

Indeed, at least two phases of dismantlement of the structure have been so far identified. The first probably began not long after the tomb was abandoned, while the second most likely was due to Late Antique or pre-modern plundering, which is widely attested in the area.

\section{Preliminary report on the pottery from the 2018 excavation}

During the March-April 2018 season at Saqqara, the study of pottery mainly focused on the materials found during the previous campaign (2017) and on the preliminary processing of the ceramics discovered during the 2018 season.

The vast majority of the pottery sherds belong to socalled "embalmers' caches" dated to the Late Period, and possibly more specifically to the fifth century BCE. ${ }^{40}$ These deposits possibly include both materials discarded at the end of the embalming process and funerary offerings.

The ceramic materials are highly consistent in terms of shape, clay, types, surface treatment and dimensions. The most represented types are: bowls (colloquially defined as "goldfish" bowls), bottles, plates, and pot stands.

The bowls (Fig. 22) usually have an in-turned rim, a flattened-on lip, slightly internally and externally thickened, a globular body, and a convex, slightly pointed base. The rim diameter ranges consistently between 16 and $17 \mathrm{~cm}$, while a lower percentage of "goldfish" bowl has an average diameter of $30 \mathrm{~cm}$; some specimens of this type have a smaller diameter, about $10 \mathrm{~cm}$. The surface treatment usually consists

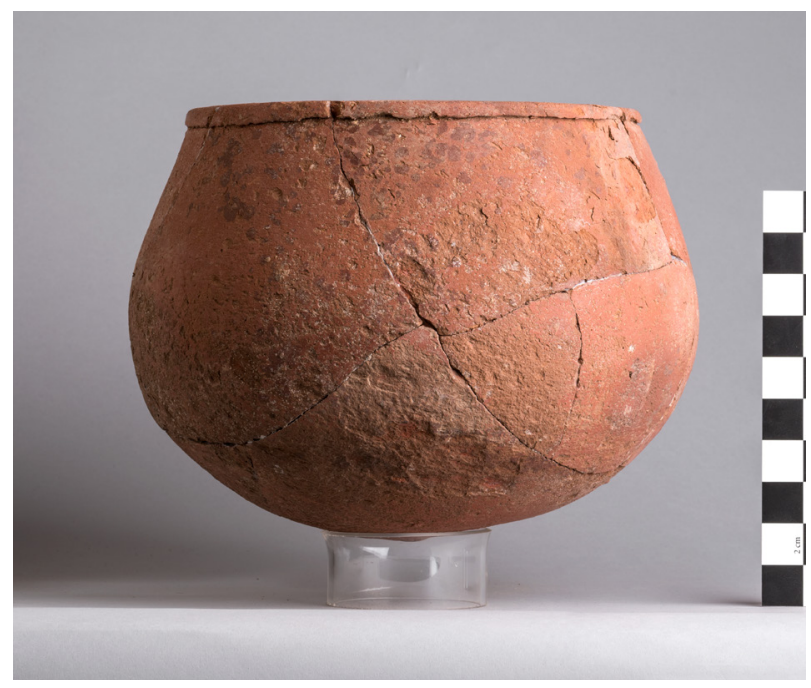

Fig. 22: Example of a "goldfish" bowl. Photo by Nicola Dell'Aquila/Leiden-Turin Expedition to Saqqara. 

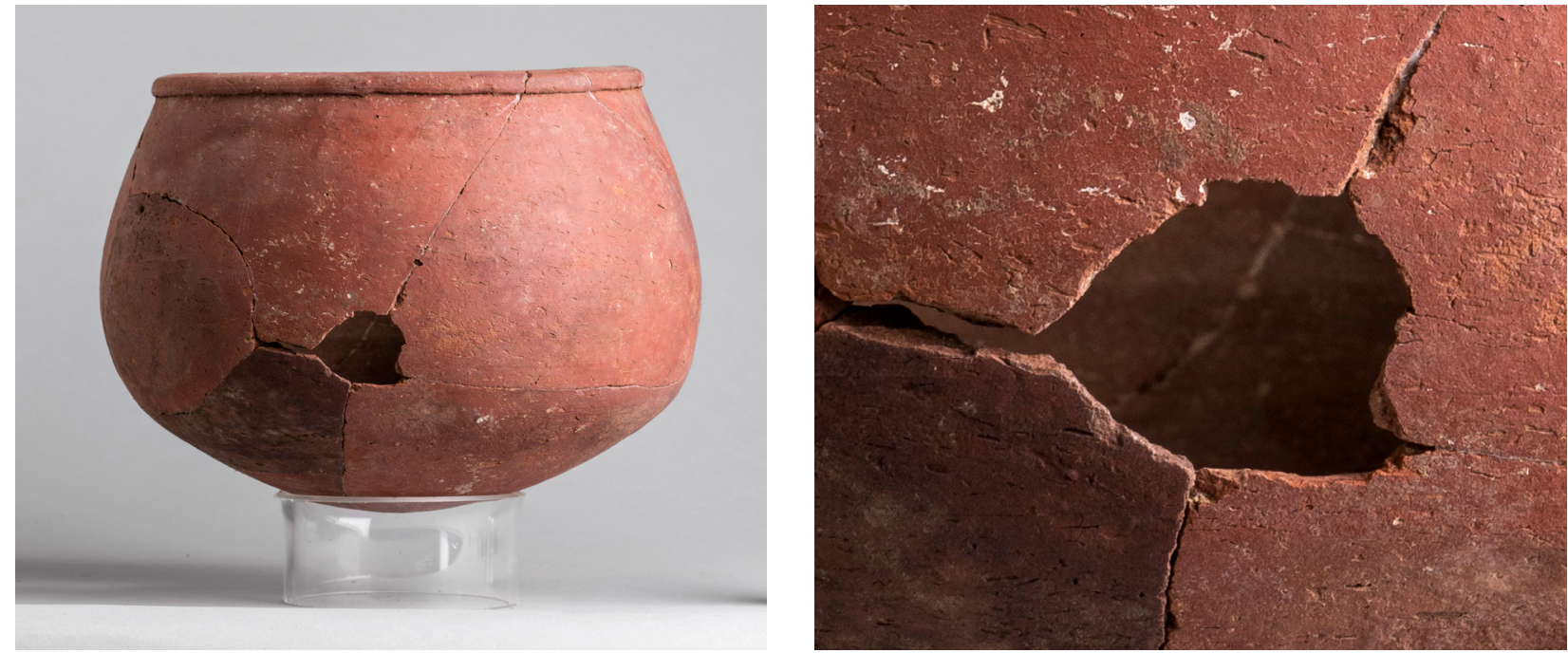

Fig. 23: "Goldfish" bowl with ritual killing hole and detail. Photos by Nicola Dell'Aquila/Leiden-Turin Expedition to Saqqara.

of a red slip applied to the exterior (with rare dripping on the inner surface) and poorly burnished with horizontal strokes. These bowls are usually made from Nile Silt J1 (according to the fabric classification system specifically devised for the site by Janine Bourriau and further developed by Barbara Aston) and often have a grey core resulting from uneven firing.

Some of these specimens have post-firing holes, pierced from the exterior to the interior with a sharp object, suggesting an interpretation as "ritual killing holes" (Fig. 23), perhaps related to the de-functionalisation of the pots just before their deposition. ${ }^{41}$

Some other specimens have traces of inscriptions, so-called "charcoal dockets" (Fig. 24), most probably written with black ink, very faded, which have been previously interpreted as relative to the four Sons of Horus, ${ }^{42}$ but need to be further investigated.

The second most represented pottery type from the embalmers' caches is the bottle (Fig. 25), characterised by a vertical rim, a slightly externally thickened, cylindrical neck with a groove $0.5 \mathrm{~cm}$ below the rim, a rounded shoulder, a cylindrical body and a convex base. The external surface is red-slipped and burnished. The clay is Nile Silt J2 (according to the site-specific fabric classification system), usually finer than the one used for the manufacturing of the "goldfish" bowl. Inscriptions have not been found on this type of vessel. On average, the diameter is $10 \mathrm{~cm}$ and the height around $30 \mathrm{~cm}$. Another type of bottle is bigger - about $40 \mathrm{~cm}$ tall - and has a broader rim and broader shoulder, and a larger ovoid body. The neck of this type is graced by two shallow ridges

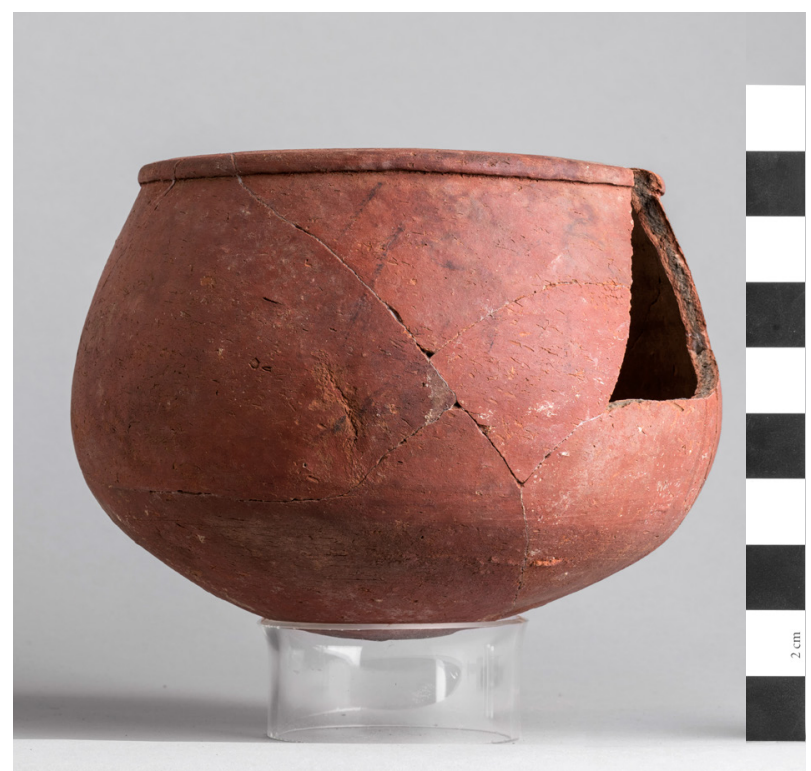

Fig. 24: "Goldfish" bowl with a "charcoal docket". Photo by Nicola Dell'Aquila/Leiden-Turin Expedition to Saqqara.
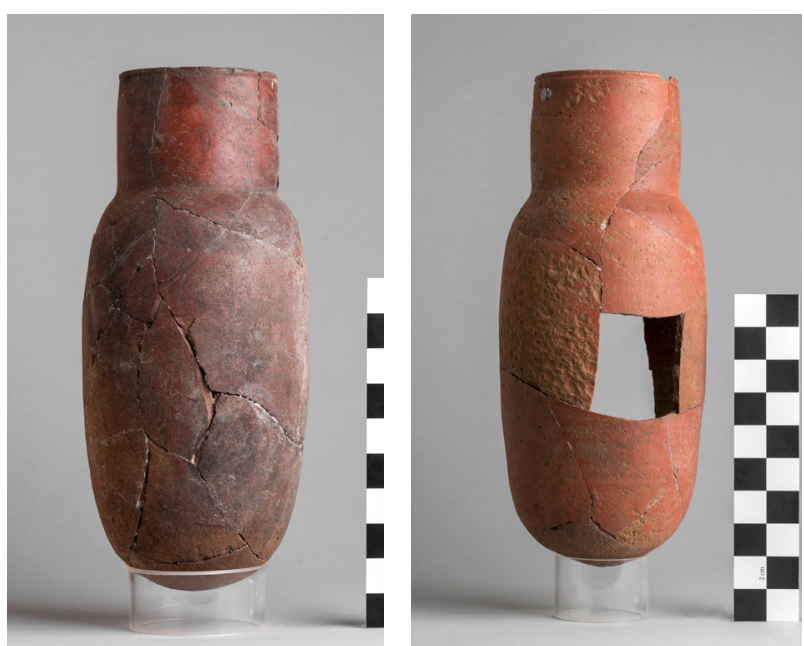

Fig. 25: Bottles. Photos by Nicola Dell'Aquila/Leiden-Turin Expedition to Saqqara. 

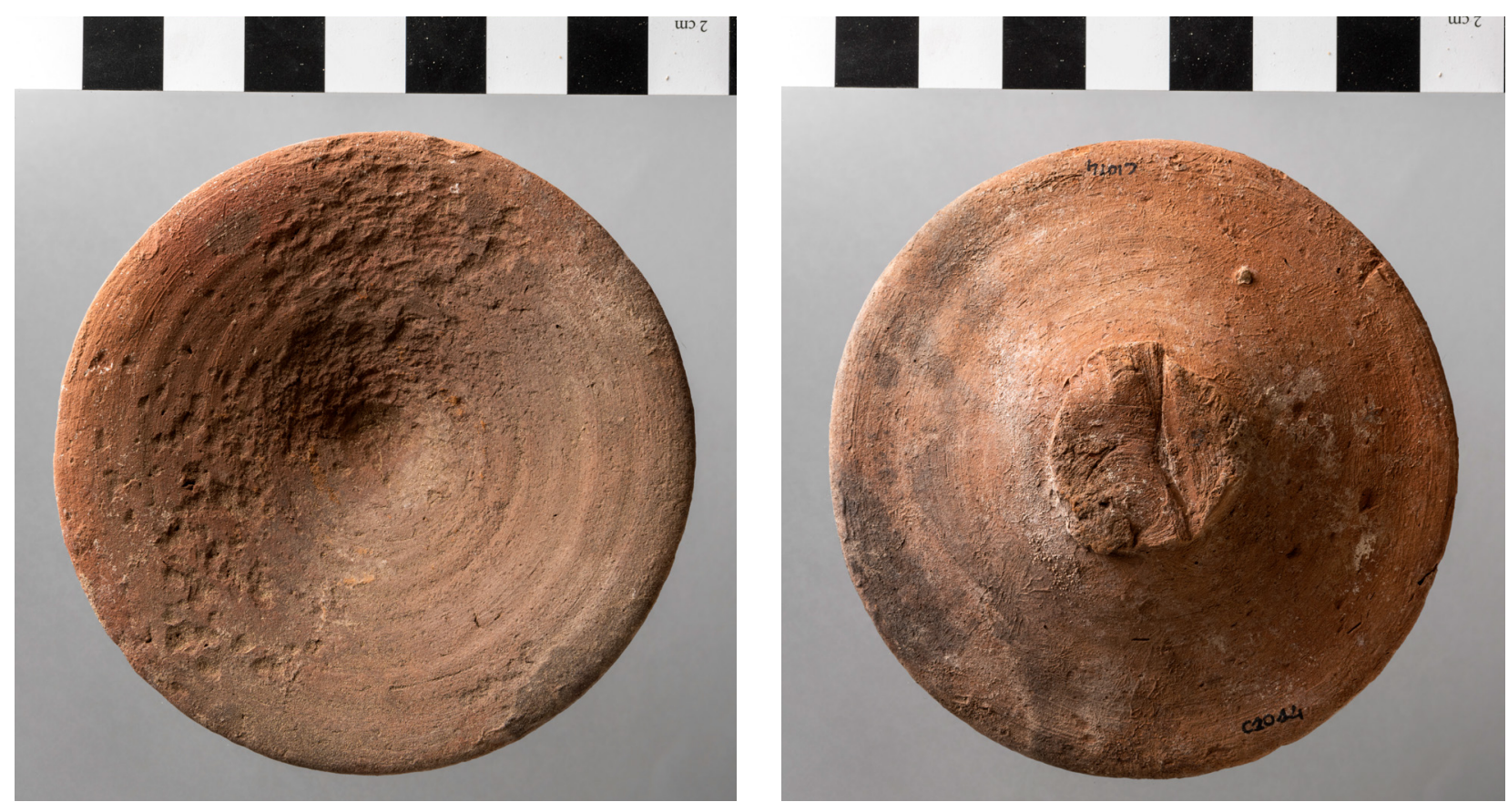

Fig. 26: Example of a plate. Photo by Nicola Dell'Aquila/Leiden-Turin Expedition to Saqqara.

about 1 to $2 \mathrm{~cm}$ below the externally thickened rim. The plates (Fig. 26) are quite small, with an average diameter of $16 \mathrm{~cm}$, a direct rim, an oblique wall and a flat, string-cut base, sometimes modelled. Their surface is untreated and their crude manufacture makes them quite uneven in shape. The interior usually displays a shallow depression with a finger mark in the middle.

Pot stands (Fig. 27) are quite standardised. They have an everted rim, a cylindrical wall and an externally thickened base. They range in diameter between 13 and $16 \mathrm{~cm}$ and are slightly uneven in shape. The surface generally appears to be untreated, except in some specimens that are covered with a light wash. None of the examples found shows any wear-marks, which suggests that they were used over a short period of time. During the 2018 campaign, new materials were uncovered in the same area. It was immediately evident that they belonged to the same embalmers' caches; indeed, many fragments joined the partially reconstructed shapes, increasing the percentage of complete items. It is clear that these caches were disturbed in antiquity, as suggested by the presence in these contexts of Late Antique materials such as sherds of Late Roman 1 and 7 amphorae (fifth-seventh century CE).

Season 2018 also focused on the preliminary sorting and study of the ceramic materials from the ongoing excavation. The pottery from the Late Antique levels mainly consists of Late Roman 7 and 1 amphorae, Aswan Ware (mainly open shapes), locally made table wares (mainly bowls) and cooking wares (mainly represented by pans with horizontal handles). The preliminary study of these materials indicates a chronological horizon consistent with a fifth-seventh century CE dating.

The preliminary study of the ceramic materials from shaft 131 indicates a mixed chronology, ranging from the New Kingdom to the Late Antique period. The most abundant materials are Late Roman 7 and 1 amphorae, Late Period bottles and "goldfish" bowls, Marl D New Kingdom amphorae (mainly preserved in fragmentary conditions) and a few body sherds of New Kingdom Blue Painted Ware.

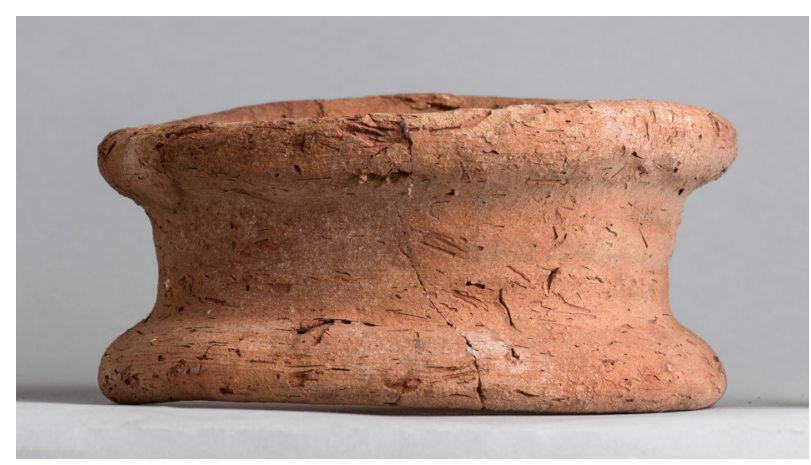

Fig. 27: Pot stand. Photo by Nicola Dell'Aquila/Leiden-Turin Expedition to Saqqara. 

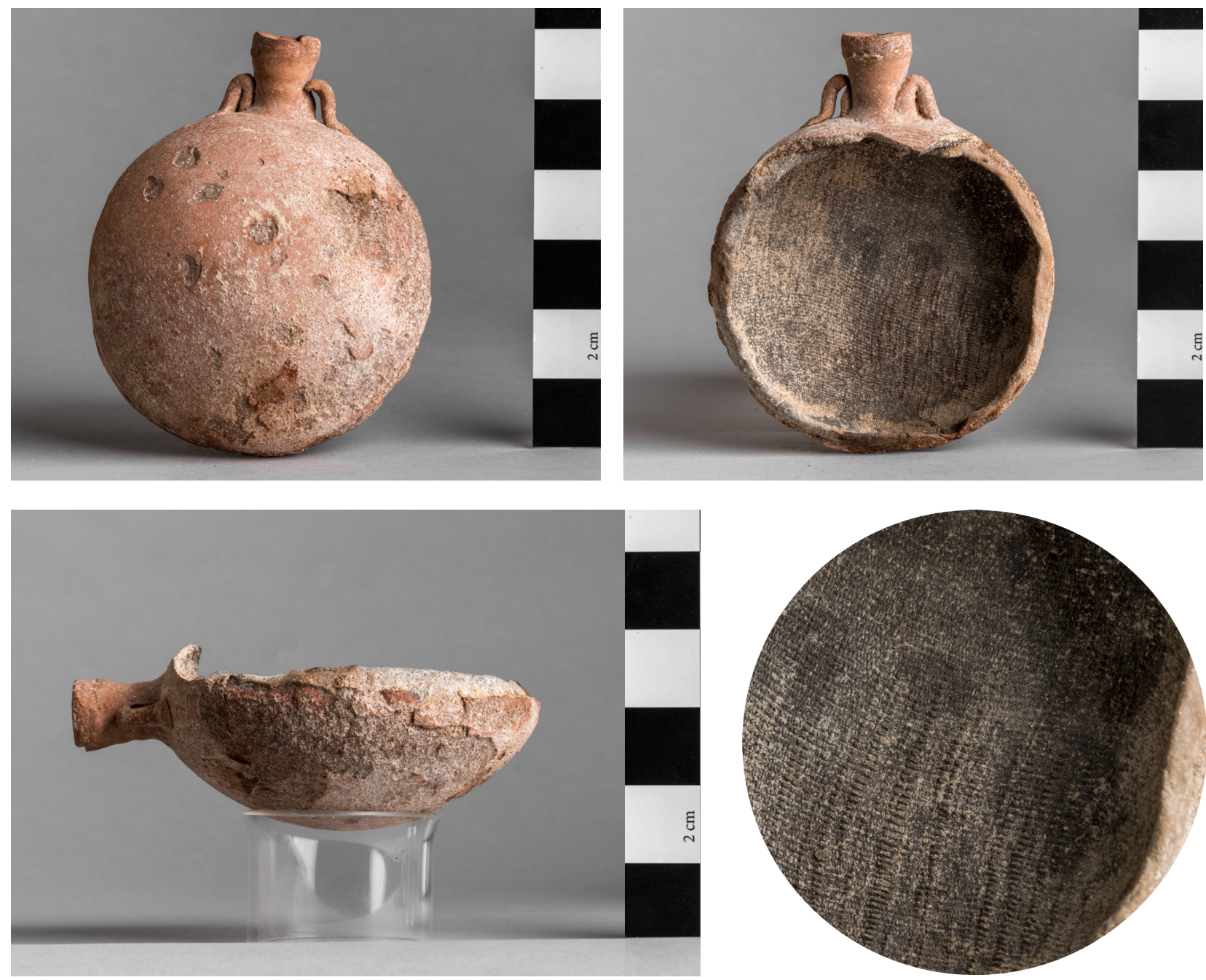

Fig. 28: Pilgrim flask with detail showing the interior surface and the impression of a textile. Photos by Nicola Dell'Aquila/ Leiden-Turin Expedition to Saqqara.

A few of the excavated items are peculiar. One of the embalmer's caches yielded a Marl A pilgrim flask (K2 marl according to the site fabrics classification system) (Fig. 28). One face is preserved, with a vertical $\operatorname{rim}(\varnothing 2 \mathrm{~cm})$, flattened at the lip, and a short cylindrical neck. Two vertical, pinched handles from the lower neck to the shoulder are still preserved. The body is lentoid. The surface is uncoated and has a pale colour. A series of concentric lines are incised on the outside of the body. The state of preservation is good, although incomplete. The exterior surface is slightly eroded, and salt incrustations are noticeable on both the exterior and the interior surfaces. Interestingly, there is a negative impression of textile on the interior (Fig. 28, right), most probably related to the manufacturing process: it is still perfectly preserved and covers the whole interior. ${ }^{43}$ Since only one half of the flask is preserved, it was probably reused after breaking.
Further remarkable and quite peculiar types of vessels were found in association with the embalmers' cache, namely, a series of cups manufactured from Marl A. In 2017, only one specimen had been found, whereas in 2018 five more were retrieved. Four of these (Fig. 29) were found together in the same cache. One still contained embalmers' materials, and another two were found one inside the other. The diameter of each bowl is about $10-11 \mathrm{~cm}$, and they are between 7 and $10 \mathrm{~cm}$ tall. The rim is vertical, thinned at the lip; the walls are vertical and the base is either flat or slightly pointed. The surface is uncoated, with a pale firing surface and no decoration. The vessels bear hieratic labels written in black ink about $2 \mathrm{~cm}$ below the rim (see the section "Abandonment and reuse of the area" above).

VG, AS

\section{Preliminary analysis}



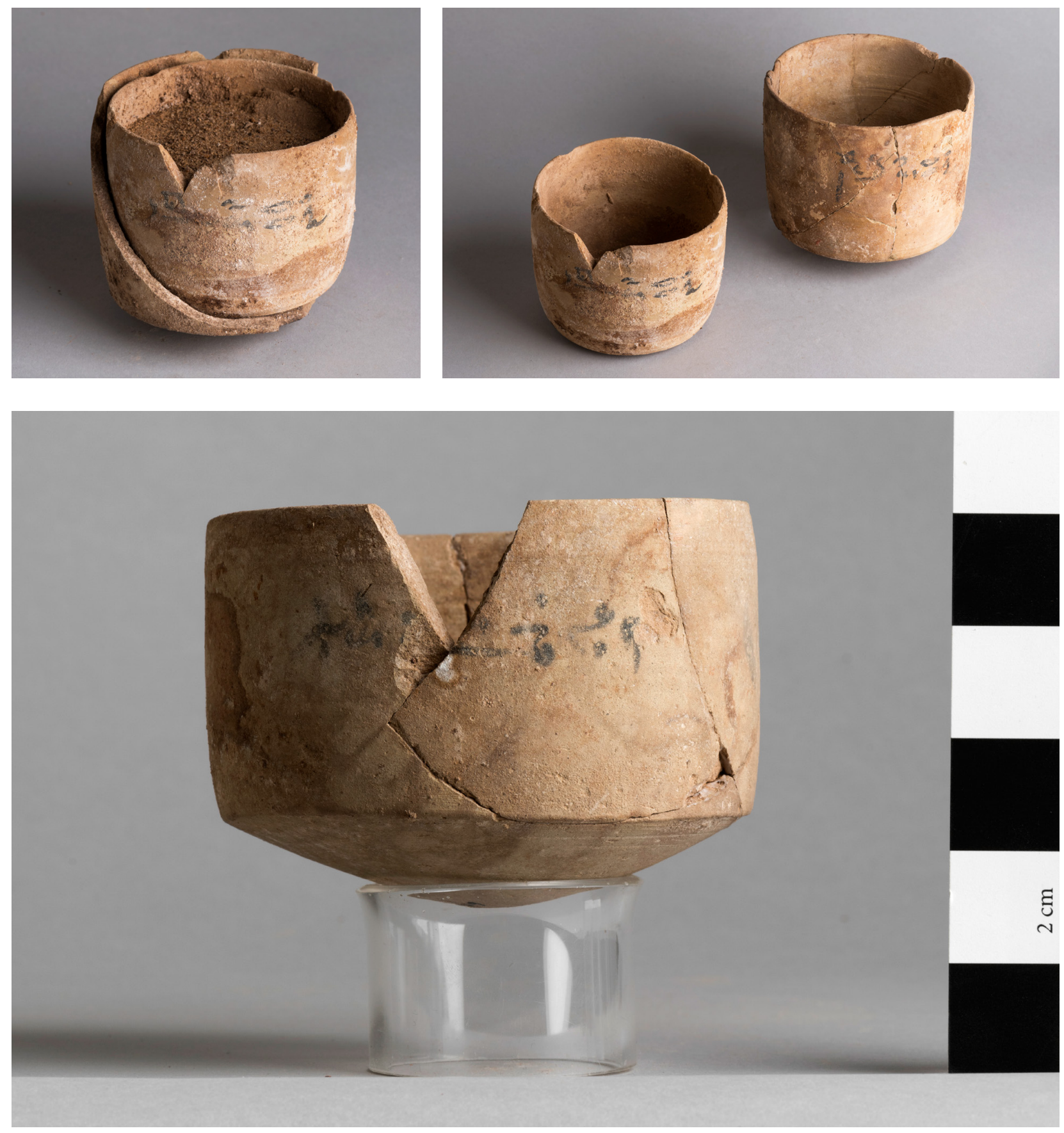

Fig. 29: Marl clay cups with hieratic labels. Photo by Nicola Dell'Aquila/Leiden-Turin Expedition to Saqqara.

\section{of the human remains}

Two different types of skeletal material were found during this season: loose surface material that cannot be traced back to a complete skeleton, and four individual burials.

The loose surface material consisted of 577 individual bones. Of these, 58 were not human and 18 were found out of context. This leaves us with 502 individual human bones that can be ascribed to a well-defined archaeological context. These can be used to determine the MNI (minimum number of individuals) for the area excavated in 2018.
Of the 114 contexts identified during the 2018 season, 36 contained human bone material. Of these, context 221 , most likely a rather recent dump originated from the excavation of nearby tombs, contained most of the pieces, with 209 individual bones. Context 296, a deposit resulting from the plundering of the surrounding funerary shafts, came second with 82 bones. Six more contexts ${ }^{44}$ fall in the 11-to20-piece range, while most of the remaining ones ${ }^{45}$ contained between 1 and 10 individual bones. The MNI is determined by examining each of the bone fragments in a given context and estimating how 


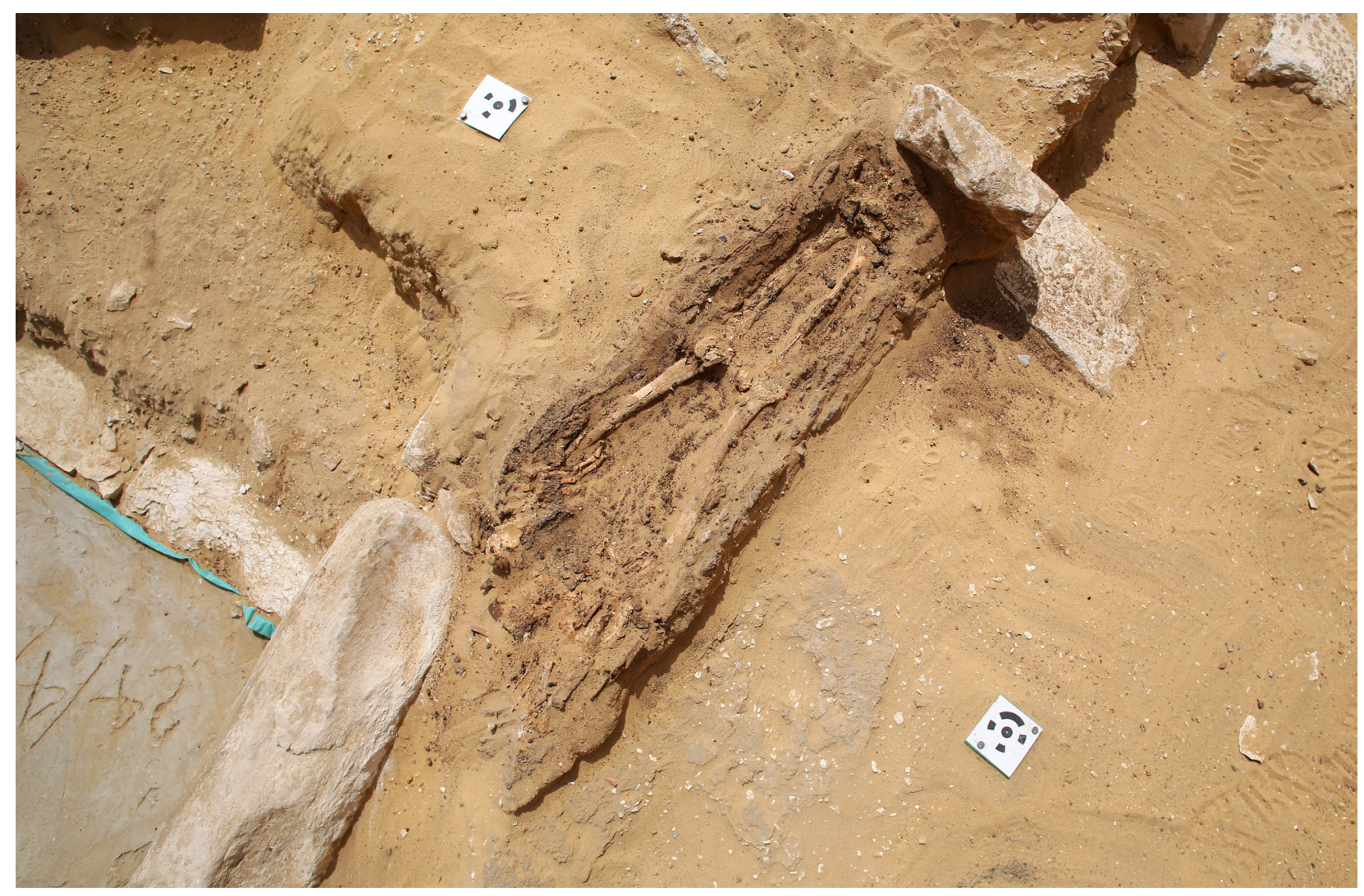

Fig. 30: Zenithal view (south-west up) of burial no. 2 (context 261). The body and coffin are preserved only to a maximum length of $122 \mathrm{~cm}$. At the bottom left corner of the image, the north-west edge of the funerary shaft of chapel 270 can be seen. Photo by Luca Perfetti/Leiden-Turin Expedition to Saqqara.

many individuals they represent. Doing this for each context separately is problematic, as commingling and scattering between contexts (and over the whole site in general) has definitely happened throughout the years. The MNI should thus be calculated for the whole range of individual bones excavated during the 2018 season. This results in a MNI of nine, based on the presence of five left adult humeri and four right subadult tibiae. As this is only the minimum number of individuals, the true number of individuals scattered throughout the area of this year's excavation is probably higher, but it is of course impossible to determine their exact number.

In addition to the loose bone material, we found and excavated four burials. These have not been analysed yet, but some information regarding their context can already be given.

Burial no. 1, ascribed to context 249 , was tentatively dated to the Late Antique period. The individual, a subadult, was wrapped in a piece of cloth before being buried in a small pit lined with mud (see Fig. 6, Fig. 7 above). The limited size of the burial (the cloth had a total length of $28 \mathrm{~cm}$ and a maximum width of
$11 \mathrm{~cm}$ ) allowed the bundle to be removed in its entirety, after context documentation, for further careful analysis at the anthropologist's desk. The sand around the area was sieved to check for additional finds that could belong to the burial. Preliminary observations ${ }^{46}$ of the cloth content indicated that the individual was of perinate/neonate age.

A second burial (context 261), located to the north of the funerary shaft of chapel 270, consisted of a badly preserved wooden coffin with the lower body of an adult individual (Fig. 30).

The coffin and the body were cut away from the pelvis upwards by a later robbery pit dug with the aim of reaching the adjacent funerary shaft. The individual was buried in a supine position, the head roughly to the east, the arms stretched out and the hands on the pelvis. As the preservation of the skeletal material was quite poor, not much could be determined in the field, although measurements of long bones were taken.

Burial no. 3 (context 267) was found to the northeast of chapel 135, covered by the wind-blown sand deposit (context 150) that seems to date from the 


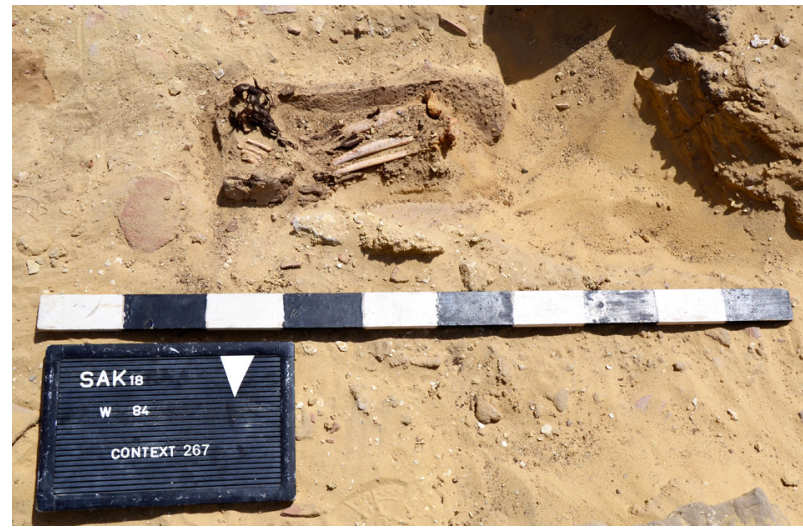

Fig. 31: Badly damaged remains of burial no. 3 (context 267). Photo by Nico Staring/Leiden-Turin Expedition to Saqqara.

post-Ramesside phase of abandonment of the funerary chapels. Unfortunately, all that survived of this burial were scanty remains of a wooden coffin with the lower limbs of a subadult individual (Fig. 31). Here, too, the upper part of the burial had suffered severe damage, most likely due to later plundering activities. Only the lower leg bones (up to the distal femur), partially wrapped in cloth, were preserved, along with the badly worn small planks ( $43 \mathrm{~cm}$ long and $18 \mathrm{~cm}$ wide) they rested upon.

Lastly, burial no. 4 (context 275) was above context 150 - the above-mentioned wind-blown sand deposit - in what appears to be the same layer as burial no. 2. As in that interment, the deceased was a subadult wrapped in cloth, lying supine with his/her head to the east (Fig. 32). No traces of a mud-brick lining or a wooden coffin could be identified. The burial was lifted in its entirety as it was and placed in storage for further analysis. During its removal, two metal wristbands, one on each wrist, were found (see Fig. 8 above). A preliminary study of the remains ${ }^{47}$ indicates that the individual buried here was an infant.

During the 2018 season, part of the underground chambers accessible through shaft 131 were also excavated. The bone material retrieved from these spaces, though, will be fully analysed only when the excavation of the chambers is completed. A preliminary examination indicates that at least four different individuals were buried there.

Finally, two individuals excavated in 2017 were studied in the 2018 season: the one from context

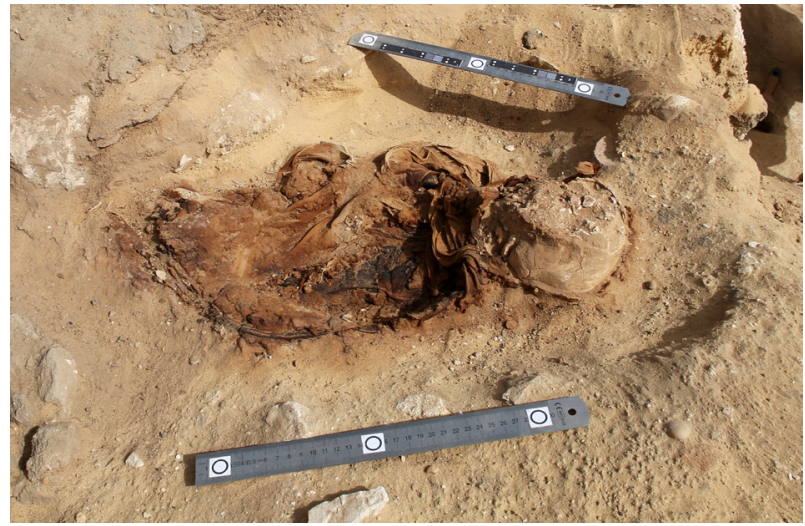

Fig. 32: Remains of a subadult (burial no. 4, context 275) wrapped in linen textile, seen from the south-east. Photo by Luca Perfetti/Leiden-Turin Expedition to Saqqara.

148, a male adult who died in middle age (36-49 years old) and whose skull still showed remains of the hair; and the probably male individual from context 162, also adult, but whose age-at-death could not be estimated due to the incompleteness of the skeleton.

Overall, the 2018 Leiden-Turin season at Saqqara yielded interesting bone assemblages, which will be studied in greater detail in 2019.

SS, AJS

\section{Architectural conservation report}

Restoration work was done in the two Ramesside chapels found in 2017, with the kind assistance of local restorers. The north wall of the small chapel (context 125) was put back in its original position. The walls of the other chapel (context 135) were consolidated. The excavation of the area behind the latter chapel uncovered two blocks, which will be put back in their original position on north wall of the chapel in 2019.

The conservation work on the site was carried out during the latter part of the season, from 15-25 April. The size of the mud-bricks used in all the strengthening works was $20 \times 10 \times 7 \mathrm{~cm}$. The activities undertaken this season were essentially confined to maintenance of standing remains. They included the following:

1. Installation of a protective timber ventilated opening cupboard on a steel frame around the four-sided stela south of the tomb of Meryneith.

2. Completion of the strengthening and protection 


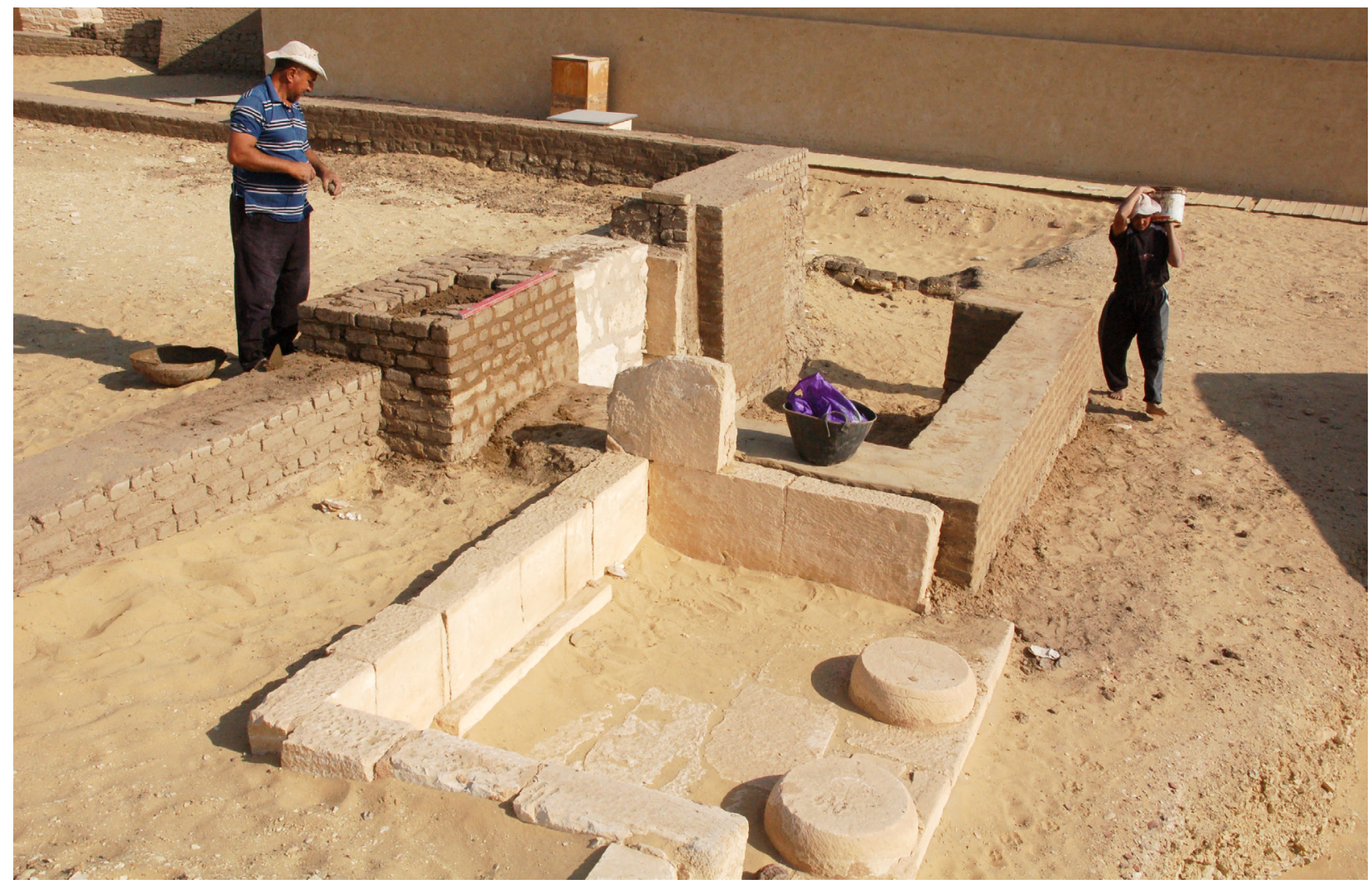

Fig. 33: Strengthening and capping of the outer wall of the tomb of Ry in the southern part of the Dutch-Italian concession. Photo by Nicholas Warner/Leiden-Turin Expedition to Saqqara.

of the tomb of $\mathrm{Ry},{ }^{48}$ commenced in 2017, including the capping of the walls of the entrance area (Fig. 33).

3. Strengthening of the north wall of the tomb of Pay.

4. Strengthening of the two western corners of the tomb of Iniuia.

5. Strengthening of the inner and upper faces of the south wall of the first courtyard of the tomb of Horemheb.

6. Re-plastering the reconstructed elements of the second courtyard of the tomb of Tia with a lime plaster using a diluted bonding agent to improve adhesion with the limestone rubble substrate (Addibond 65). This was done to test the durability of this kind of plaster before extending the treatment to the whole tomb.

7. Limestone rubble consolidation of a collapsed section of the fill of the north pylon of the tomb of Horemheb abutting the tomb of Tia (Fig. 34).

8. Securing the metal entrance doors to the subterranean part of the tomb of Maya with new steel catches and re-plastering the brick surround.

9. Construction of temporary timber protective boxes around the newly-discovered Ramesside tomb chapels north of the tomb of Maya (Fig. 35).

In addition, a discussion was held with the Directors of the Mission to determine priorities for the next season. It was agreed that we would focus on additional maintenance of mud-brick walls, including the tombs of Horemheb (south wall, internal courtyard, pylons), Ptahemwia (exterior walls) and Meryneith (forecourt). A preliminary design will be produced

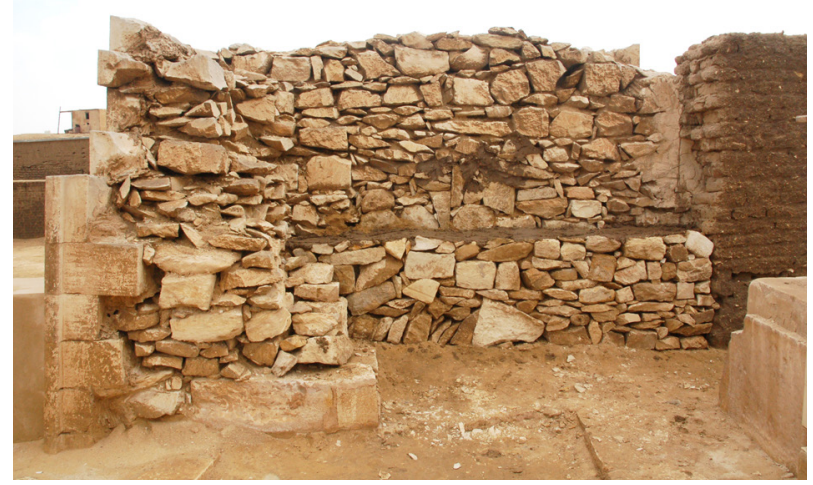

Fig. 34: North face of the pylon of Horemheb's tomb, with the strengthened rubble fill. Photo by Nicholas Warner/ Leiden-Turin Expedition to Saqqara. 


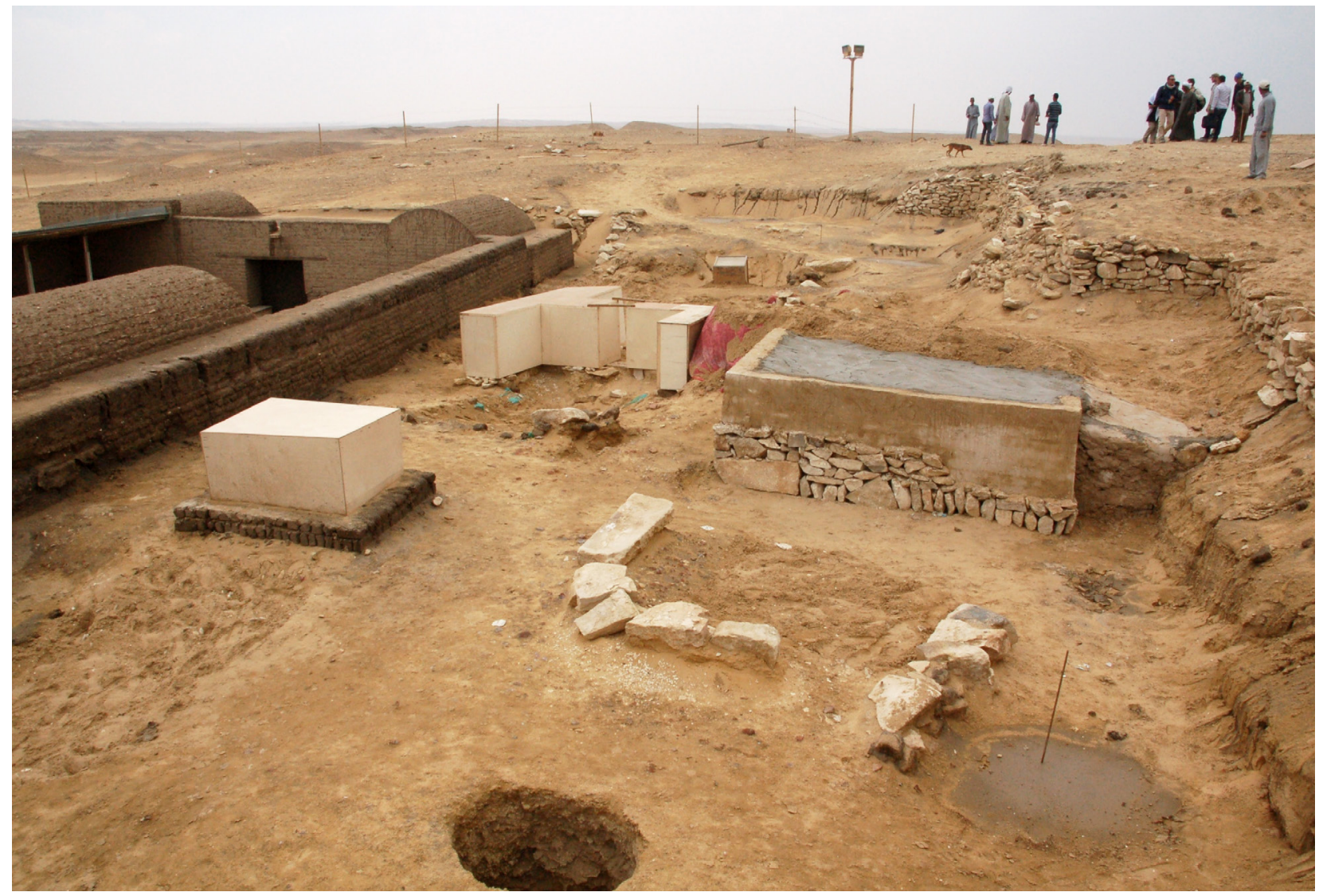

Fig. 35: The new protective covers devised for the Ramesside chapels found during the 2017 and 2018 seasons. Photo by Nicholas Warner/Leiden-Turin Expedition to Saqqara.

of new free-standing small steel frame shelters to be built over the three Ramesside chapels north of the tomb of Maya. A decision about future conservation strategies for the large tomb to the west of these chapels will have to await further excavation.

Other potential tasks related to site management include the adaptation of the tomb of Tia to accommodate a display of blocks underneath the existing shelter and the replacement of the shutters of the shelter of Ptahemwia with a new design that is easier to open.

On the night of April 24/25 there were a severe hailstorm and rainfall on the site, which heavily affected all the mud-brick structures (Fig. 36). This was followed by further rain throughout April 25, which made the damage worse. It was therefore decided that a stronger capping brick should be trialled next season and used on the upper two courses of all exposed mud-brick walls. Experiments will be made in the coming months to develop a stronger brick using lime and fly-ash additives. It is also advised that a 'sacrificial' mud plaster layer be applied to large areas of new brickwork on the north and west sides of each tomb complex to reduce the future impact of such events.

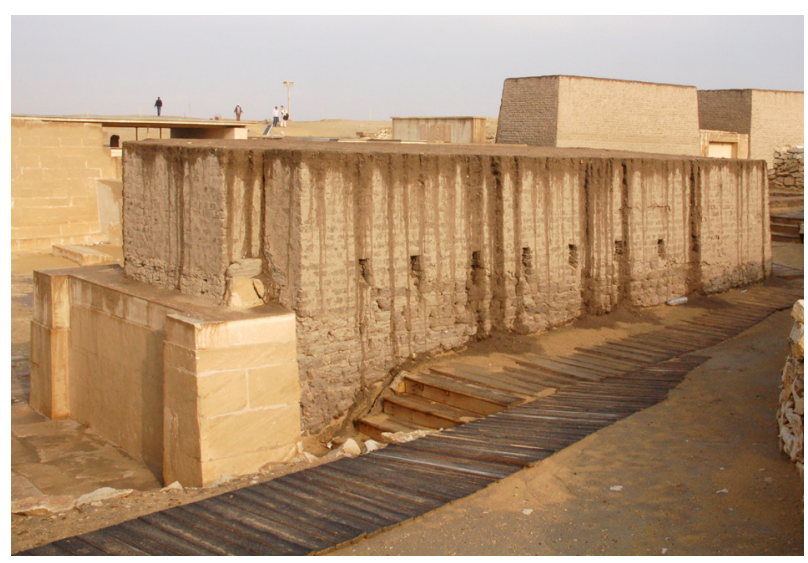

Fig. 36: Effects of the severe rainstorm of April 24/25 on the north section of the easternmost pylon of Horemheb's tomb. Photo by Nicholas Warner/Leiden-Turin Expedition to Saqqara. 


\section{Notes}

${ }^{1}$ For a recent summary of this story, cf. Weiss, in Ter Keurs and Wirtz (eds.), Rijksmuseum van Oudheden Leiden, 2018, pp. 459-64.

${ }^{2}$ Lepsius, Denkmäler, Text Band I, 1897, pp. 182-84; Lepsius, Denkmäler, Abtheilung I, Band I, 1849-1859, pl. 33; Lepsius, Denkmäler, Abtheilung III, Band VII, 1849-1859, pl. 240.

${ }^{3}$ Cf. https://www.rmo.nl/en/research/excavations/ saqqara/ (accessed on 24 May 2018).

${ }^{4}$ Resulting, for example, in the discovery and publication of the tomb of Meryneith: Raven and van Walsem, The Tomb of Meryneith, 2014.

${ }^{5}$ Hosted within the Vidi-talent scheme (dossier no. 016. Vidi.174.032 at the Leiden University Institute for Area Studies [LIAS]): https://www.nwo.nl/onderzoeken-resultaten/onderzoeksprojecten/i/52/28952.html

${ }^{6}$ See Weiss, in Rüpke, Urban Religion, (forthcoming). Some first results of the project will soon be published in the PALMA series of the RMO, cf. https://www. sidestone.com/books/perspectives-on-lived-religion (accessed on 12 March 2019).

${ }^{7}$ E.g. Kolen et al. (eds.), Landscape Biographies, 2015.

${ }^{8}$ Atkinson et al. (eds.), Cultural Geography, 2005, p. xv.

${ }^{9}$ Cf. e.g., recently, Franzmeier, Die Gräberfelder von Sedment, 2017, pp. 334-36.

${ }^{10}$ For a shorter version of this 2018 preliminary report, see Del Vesco and Weiss, in Saqqara Newsletter 16 (2018).

${ }^{11}$ The 2018 season saw the participation of: Rafat Kis, Guda Abdel Khaled, Mohammed Ali, Samir Abd Hamad, Sabri Abu Said, Ahmed Fekri, Assam Rashid, Abdel Nabi Rashid, Abdel Rahman Fatri, Islam Bahari, Mohammed Abu Yazid, Isham Nasr Mahmud, Hishab Abdel Karim, Yussef Hammadi, Sherif Shahat, Shahati Gaber, Assam Sada Khalil, Hwdid Mahmud, Talal Abd Massura, Mohammed Garwash, Mohesin Ibrahim Shahib, Ahmed Mohammed Fekri Shahib, Moharis Abdallah, Abdel Nabil Mahmud, Ahmed Gamal, Mohammed Hadim, Mahdi Abdel Nabil Abdel Wahat, Said Ragab, Tamer Sahid Ibrahim, Omar Ramadan Abdel Hati, Gaballa Abu el id, Abdel Mohasin Ali Hessin, Sami Ashur Mohammed, Mahus Beheri.

${ }^{12}$ http://www.sitech-3dsurvey.polimi.it/?page_id=2456. The survey in the field was performed by Francesco Fassi, Alessandro Mandelli and Luca Perfetti, within the framework of the 2018 Dutch-Italian mission. The subsequent processing of the data was carried out by Fausta Fiorillo and funded by the ERC Consolidator Grant 681673 (excavated area) and the Friends of Saqqara (tombs of Maya and Tia).

${ }^{13}$ Rossi, MDAIK 74 (2018); Perfetti et al., Int. Arch. Photogramm. Remote Sens. Spatial Inf. Sci., XLII-2/W3 (2017).

${ }^{14}$ For a preliminary report on the 2017 season see Raven, et al., JEOL 47 (2018), forthcoming.

${ }^{15}$ The date of most of the pottery ranges between the third and the seventh century CE.

${ }^{16}$ For parallels, see Raven and van Walsem, The Tomb of Meryneith at Saqqara, 2014, pp. 240-41, cat. 78 (pair: SAK 2001-92) and cat. 79 (SAK 2002-99) with reference to Schneider, The Memphite Tomb of
Horemheb, 1996, p. 49, Cat. 311-4, and to Raven, The Tomb of Maya and Meryt, 2001, p. 55, Cat. 308, pl. 23, dated to the Late Period. See also the Roman child mummy currently in the museum Meermanno in The Hague (the Netherlands), which wears two bracelets adorned with snake heads (Meermanno Museum inv. no. 290/437, Boddens Hosang, De Egyptische verzameling, 1989, pp. 80-81). Those from child burial no. 4 (context 275) could be a less elaborate version of these serpentiform bracelets. Object SAK 2007-21 is a less corroded parallel, cf. Raven, The Tombs of Ptahemwia and Sethnakht, (forthcoming).

${ }^{17}$ Cf. Pasquali in Bárta et al. (eds.), Abusir and Saqqara in the Year 2015, 2017, pp. 557-82; Staring in Verschoor et al. (eds.), Imaging and Imagining, 2017, pp. 95-113.

${ }^{18}$ A similar basket was retrieved, in the 2017 season, from a very large robbery pit in a close-by area. Objects testifying to nineteenth century digging were actually found as early as the late 1970s, for example, during the excavation of the tomb of Horemheb, when an iron turriah (a typical Egyptian hoe) was unearthed, as well as "three plaited palm-fibre baskets in a good status of preservation" in the statue room of the tomb; cf. Martin, Tutankhamun's Regent, 2016, p. 3.

${ }^{19} \mathrm{Cf}$. Aston in Aston et al. (eds.), Under the Potter's Tree, 2011, pp. 45-79. We are grateful to Susanne Töpfer for the preliminary reading of the inscriptions, which will be fully discussed in a future publication.

${ }^{20}$ Raven et al., JEOL 47 (2018), forthcoming.

${ }^{21}$ Hema, Group Statues of Private Individuals, 2005, p. 368.

${ }^{22}$ The best parallel is perhaps found in TT 54 in Thebes, cf. Polz, Das Grab des Hui und des Kel, 1997, p. 40 and pls 3 and 15b, but others are known from both Thebes and Saqqara, e.g., with less detail, Zivie, La Tombe de Thoutmes, 2013, p. 112-3, fig. 21 and pl. 15 or Hari, La tombe thébaine du père divin Neferhotep, 1985, pl. VII.

${ }^{23}$ Relief-decorated blocks from the chapel of Wenefdjedsen, MFA 24.981 (temp. Ramesses II; Teti Pyramid cemetery). Cf. Dunham, JEA 21 (1935), pp. 149-50, pl. 18.

${ }^{24}$ E.g. Leiden AST 69, cf. Boeser, Beschrijving van de Egyptische verzameling, 1913, p. 22 and pl. X.

${ }^{25}$ This would fit well with the notion that the (extended) family became increasingly important in tombs in the course of the New Kingdom and especially in the Ramesside period. Cf. Pirelli, in Eyre (ed.), Proceedings of the Seventh International Congress of Egyptologists, p. 878, and Weiss, in Staring et al. (eds.), Perspectives on Lived Religion (forthcoming).

${ }^{26}$ E.g. Hari, La tombe thébaine du père divin Neferhotep, 1985, p. 59 and pl. LXXVIII.

${ }^{27}$ In this respect it differs from the stela found in chapel 270, as its bottom part, now in the Petrie Museum of Egyptian Archaeology, University College London (UC 14463), actually carries seven rows of inscription and the figures of the owners and relatives occupy only the upper part of the stela.

${ }^{28}$ Leiden inv. no. AM 8-b and AP 11 cf. Boeser, Beschrijving van de Egyptische verzameling 1913, p. 7 and pl. X; Giovetti and Picchi, Egitto splendore millenario, 2015, p. 268, cat. V.32 and p. 266, cat. V.27; Berlin inv. no. ÄM 31009, cf. Leclant (ed.), Ägypten II, 
1980, p. 290 and fig. 320.

${ }^{29}$ Hawass, Secrets from the Sand, 2003, pp. 154-55, fig. on p. 156; Firth and Gunn, Teti Pyramid Cemeteries, 1926, p. 67.

${ }^{30}$ Boston MFA 00.690a-b, cf. https://www.mfa.org/ collections/object/naos-of-menmaatre-em-heb-4418 (accessed on 24 May 2018).

${ }^{31}$ See also, e.g., the naos of Amenemheb, Copenhagen Carlsberg Glyptothek inv. no. ÆIN 1555, https:// www.kulturarv.dk/mussam/VisGenstand. action?genstandId $=7553453$, dated to the Nineteenth Dynasty.

${ }^{32}$ Hema, Group Statues of Private Individuals, 2005, p. 265 and pl. $122 f$.

${ }^{33}$ See KRI III, 454-55.

${ }^{34}$ Hofmann, Bilder im Wandel, 2004, p. 135; van Dijk, The New Kingdom Necropolis of Memphis, 1993.

${ }^{35}$ Compare, for instance, the parallels collected by Settgast, Untersuchungen, 1963. Our scene comes closest to the so-called "Saisfahrt", although in that procession the boat should travel on water rather than being pulled by cows.

${ }^{36}$ See Del Vesco and Weiss, Saqqara Newsletter 15 (2017), pp. 22-23.

${ }^{37}$ See Raven et al., The Memphite Tomb of Horemheb, 2011, pp. 41-46, fig. 1.27 and van Walsem et al., JEOL 35-36 (1997-2000), pp. 5-25.

${ }^{38}$ Raven et al., JEOL 47 (2018), forthcoming; Del Vesco and Weiss in Saqqara Newsletter 15 (2017), fig. 2.

${ }^{39}$ The lowest visible point on Wall 116 being, for instance, at level $56.40 \mathrm{~m}$.

${ }^{40} \mathrm{This}$ preliminary date is based on parallels from previous excavations in the New Kingdom necropolis at Saqqara: see Aston and Aston, Late Period Pottery, 2010.

${ }^{41}$ See Budka in Anderson and Welsby, The Fourth Cataract and Beyond, 2014, pp. 641-54, and Harrington, Living with the Dead, 2010, p. 39, with previous bibliography.

${ }^{42}$ Aston and Aston, Late Period Pottery, 2010, p. 59; and Raven et al., The Memphite Tomb of Horemheb, 2011, pp. 118-19, Cat. 188a-d; pp. 256-57, Cat. 240-243.

${ }^{43}$ For parallels in terms of shape and manufacturing technique see Lehmann, Die materielle Kultur, 2018, pp. 454, 498 and 502, fig. 352 and pls. 298, 318, 319.

${ }^{44}$ Context numbers 131, 222, 230, 231, 298 and 310.

${ }^{45}$ Context numbers 117, 126, 150, 158, 170, 181, 208, 209, 215, 216, 217, 226, 228, 229, 237, 242, 244, 254, 260, 261, 272, 278, 279, 280, 281, 288, 295 and 299.

${ }^{46}$ According to parameters in Cunningham at al., Developmental Juvenile Osteology, 2000.

${ }^{47}$ Based on Cunningham et al., Developmental Juvenile Osteology, 2000.

${ }^{48}$ Staring, Saqqara Newsletter 16 (2018), pp. 31-46.

\section{Bibliography}

Aston, D.A., 'tz phrt wty. The Saqqara Embalmers' Caches Reconsidered: Typology and Chronology”, in D.A. Aston, B. Bader, C. Gallorini, P. Nicholson and S. Buckingham (eds.), Under the Potter's Tree: Studies on Ancient Egypt Presented to Janine Bourriau on the Occasion of Her 70th Birthday, Leuven, Paris, Walpole MA 2011, pp. 45-79.
Aston, D.A. and B.G., Aston, Late Period Pottery from the New Kingdom Necropolis at Saqqâra: Egypt Exploration Society, National Museum of Antiquities, Leiden, Excavations 1975-1995 (EES Memoir 92), London 2010.

Atkinson, D., P. Jackson, D. Sibley and N. Washbourne (eds.), Cultural Geography: A Critical Dictionary of Key Concepts, London 2005.

Boddens Hosang, F.J.E., De Egyptische verzameling van Baron van Westreenen, The Hague 1989.

Boeser, P.A.A., Beschrijving van de Egyptische verzameling in het Rijksmuseum van Oudheden te Leiden, VI, Leiden 1913.

Budka, J., “Egyptian Impact on Pot-Breaking Ceremonies at El-Kurru? A Re-examination”, in J.R. Anderson and D.A. Welsby (eds.), The Fourth Cataract and Beyond, Proceedings of the $12^{\text {th }}$ International Conference for $\mathrm{Nu}$ bian Studies, London 2014.

Cunningham, C.A., L. Scheuer and S. Black, Developmental Juvenile Osteology, Amsterdam 2000.

Del Vesco, P. and L. Weiss, “A Brief Report on the 2017 Season (2): The Leiden-Turin Expedition to Saqqara: Excavating to the North of Maya's Tomb", Saqqara Newsletter 15 (2017), pp. 19-26.

Del Vesco, P. and L. Weiss, “The Leiden-Turin Archaeological Mission in Saqqara - Preliminary Report of the 2018 Season", Saqqara Newsletter 16 (2018), pp. 4-10.

van Dijk, J., The New Kingdom Necropolis of Memphis: Historical and Iconographical Studies, Groningen 1993.

Dunham, D., "Four New Kingdom Monuments in the Museum of Fine Arts, Boston”, JEA 21 (1935), pp. 147-51.

Firth, C.M. and B. Gunn, Teti Pyramid Cemeteries, Cairo 1926.

Franzmeier, H., Die Gräberfelder von Sedment im Neuen Reich: materielle und kulturelle Variation im Bestattungswesen des ägyptischen Neuen Reiches, I-II (Probläg 34), Leiden 2017.

Giovetti, P. and D. Picchi, Egitto splendore millenario. La collezione di Leiden a Bologna, Milano 2015.

Hari, R., La tombe thébaine du père divin Neferhotep (TT50), Geneve 1985.

Harrington, N., Living with the Dead. Ancestor Worship and Mortuary Ritual in Ancient Egypt, Oxford 2013.

Hawass, Z.A., Secrets from the Sand: My Search for Egypt's Past, New York 2003.

Hema, R.A., Group Statues of Private Individuals in the New Kingdom, I-II, Oxford 2005.

Hofmann, E., Bilder im Wandel: die Kunst der ramessidischen Privatgräber. Theben 17, Mainz 2004.

Kolen, J., J. Renes and R. Hermans (eds.), Landscape Biographies. Geographical, Historical and Archaeological Perspectives on the Production and Transmission of Landscapes, Amsterdam 2015.

Leclant, J. (ed.), Ägypten II. Das Großreich 1560-1970 v. Chr., Munich 1980.

Lehmann, M., “Die materielle Kultur der Spät- und Ptolemäerzeit im Delta Ägyptens am Beispiel von Tell el-Dab'a”, (Dissertation, Freie Universität Berlin), Berlin 2018.

Lepsius, C.R., Denkmäler aus Aegypten und Aethiopien nach den Zeichnungen der von Seiner Majestät dem Könige von Preussen, Friedrich Wilhelm IV, nach diesen Ländern gesendeten und in den Jahren 1842-1845 aus- 
geführten wissenschaftlichen Expedition, I-XIII, Berlin 1849-1859.

Lepsius, C.R., Denkmäler aus Aegypten und Aethiopien nach den Zeichnungen der von Seiner Majestät dem Könige von Preussen Friedrich Wilhelm IV nach diesen Ländern gesendeten und in den Jahren 1842-1845 ausgeführten wissenschaftlichen Expedition, Leipzig 1897.

Martin, G.T., Tutankhamun's Regent. Scenes and Texts from the Memphite Tomb of Horemheb for Students of Egyptian Art, Iconography, Architecture, and History (EES Memoir 111), London 2016.

Pasquali, S., "Les fouilles d'Auguste Mariette à Saqqara (1858-1875): les tombeaux du Nouvel Empire”, in: Bárta, M., F. Coppens and J. Krejčí (eds.), Abusir and Saqqara in the Year 2015, Prague 2017, pp. 557-82.

Perfetti, L., C. Polari and F. Fassi, “Fisheye Photogrammetry: Tests and Methodologies for the Survey of Narrow Spaces”, Int. Arch. Photogramm. Remote Sens. Spatial Inf. Sci., XLII-2/W3, 2017, pp. 573-80; https://doi. org/10.5194/isprs-archives-XLII-2-W3-573-2017.

Pirelli, R., "The Monument of Imeneminet (Naples, Inv. 1069) as a Document of Social Changes in the Egyptian New Kingdom”, in: C.J. Eyre (ed.), Proceedings of the Seventh International Congress of Egyptologists, Cambridge, 3-9 September 1995, Leuven 1998, 871-84.

Polz, D., Das Grab des Hui und des Kel: Theben Nr. 54, Mainz 1997.

Raven, M.J., The Tomb of Maya and Meryt, II: Objects and Skeletal Remains, (EES Memoir 65), London 2001.

Raven, M.J., The Tombs of Ptahemwia and Sethnakht, Leiden (forthcoming).

Raven, M.J. and R. van Walsem, The Tomb of Meryneith at Saqqara (PALMA 10), Turnhout 2014.

Raven, M.J., C. Greco, P. Del Vesco, L. Weiss, B.G. Aston, A.J. Scheers and N. Warner, "Preliminary Report on the Leiden-Turin Excavations at Saqqara, Season 2017: The Shaft of Samut and the New Area to the North of the Tomb of Maya”, JEOL 47 (2018) (forthcoming).
Raven, M.J., V. Verschoor, M. Vugts and R. van Walsem, The Memphite Tomb of Horemheb, Commander-in-Chief of Tutankhamun. V: The Forecourt and the Area South of the Tomb with Some Notes on the Tomb of Tia, Turnhout 2011.

Rossi, C., "Italian Mission to Umm al-Dabadib (Kharga Oasis) Season 2015 - Preliminary Report”, MDAIK 74 (2018) (forthcoming).

Schneider, H.D., The Memphite Tomb of Horemheb, Commander-in-Chief of Tut'ankhamūn, II. A Catalogue of the Finds, Louvain 1996.

Settgast, J., Untersuchungen zu altägyptischen Bestattungsdarstellungen (ADAIK 3), Glückstadt 1963.

Staring, N., "Keys to Unlocking the Identity of 'Tomb X': Introducing Horemheb's Army Official, Ry”, Saqqara Newsletter 16 (2018), pp. 31-46.

Staring, N., “The Mid-Nineteenth Century Exploration of the Saqqara New Kingdom Necropolis”, in: Verschoor, V., A. J. Stuart and C. Demarée (eds.), Imaging and imagining the Memphite Necropolis: Liber Amicorum René van Walsem, Leiden 2017, pp. 95-113.

van Walsem, R., G. Martin, B. Aston and E. Strouhal, "Preliminary Report on the Dutch Excavations at Saqqara, Season 2000", JEOL 35-36, 1997-2000, pp. 5-25.

Weiss, L., "Immortality as the Response of Others", in: N. Staring, H. Twiston Davies and L. Weiss (eds.), Perspectives on Lived Religion: Practices - Transmission - Landscape, Leiden (forthcoming).

Weiss, L., "Sakkara blijkt meer dan een begraafplaats", in: P. Ter Keurs and W. Wirtz (eds.), Rijksmuseum van Oudheden Leiden - Een geschiedenis van 200 jaar, Leiden 2018, pp. 459-64.

Weiss, L., "The City of the Dead or: The Making of a Cultural Geography”, in: J. Rüpke (ed.), Urban Religion (forthcoming).

Zivie, A., La tombe de Thoutmes, directeur des peintres dans la Place de Maât (BUB. I.19) (Les tombes du Bubasteion à Saqqara 2), Toulouse 2013. 